\title{
Zásada přiměřenosti a zásada iniciativy při realizaci bezprostředních zásahů uskutečňovaných ze strany Policie České republiky $z$ hlediska teorie a praxe
}

The Principle of Proportionality in their Mutual Application in the Implementation of the Immediate Interventions Carried out by the Police of the Czech Republic in Terms of Theory and Practice

\author{
Pavel Všetička*
}

\begin{abstract}
Abstrakt
$\checkmark$ prǒpadě bezprostrednich zásahü se jedná o nejcitelnèjši prostredky verejnè-mocenského donucení, keteréjsou $v$ demokratickém právnim státè realizovány pouze za účelem ochrany těch nejuíznamnèjšich zákonem chráněných zájmì, jakými jsou život, zdraví, majetek ci osobni svoboda jednotlivce. V predkládaném príspèvku se zabývám izolovanè a posléze i ve vájemných souvislostech zásadou primèrenosti a zásadou iniciativy pri realizaci bezprostrednich zásabi uskutećnovaných ze strany Policie Ceské republiky. V pronich dvou kapitolách jsem se zamèril na řěeni nèkterých teoretických otázek spojených s jednotlivými zásadami. Ve tretí kapitole se vènuji analýze vybraných prípadu zaplikačni praxe, na nichž se pokoušm demonstrovat úskali pr̆ bledáni kompromisu mezi uplatnéním zásady primèrenosti a zásady iniciativy v rámci reálnébo fungování Policie Ceské republiky.
\end{abstract}

Klíčová slova

Bezprostredni zásaby; nezákonná nečinnost; Policie České republiky; préeročení pravomoci; zásada iniciativy; zásada primérenosti.

\section{Abstract}

In the case of immediate interventions, these are the most obvious means of public-power coercion, which are implemented in a democratic legal state only to protect the most important law-protected interests such as life, health, property or personal freedom of the individual. In the present work I deal with the mutual relation between the principle of proportionality and the principle of the initiative in the implementation of immediate interventions by the Police of the Czech Republic. In this context, I focused on solving a number of frequently discussed theoretical issues related to the subject. I also deal with the analysis of selected cases from application practice in which I try to prove the pitfalls in finding a compromise between the application of the principle of proportionality and the principle of initiative within the real functioning of the Police of the Crech Republic.

\footnotetext{
Mgr. Pavel Všetička, doktorand, Katedra správní vědy a správního práva, Právnická fakulta, Masarykova univerzita, Brno / Ph.D. student, Department of Administrative Studies and Administrative Law, Faculty of Law, Masaryk University, Brno, Czech Republic / E-mail: pavel.vseticka@seznam.cz
} 


\section{Keywords}

Immediate Interventions; Unlawful Inaction; the Police of the Czech Republic; the Overrun of Authority; the Principle of Initiative; the Principle of Proportionality.

\section{Úvod}

Zajištění vnitřního pořádku a bezpečnosti náleží mezi základní a trvalé úkoly každého fungujícího státu. ${ }^{1}$ Zvláště v posledních letech se vzhledem $\mathrm{k}$ narůstajícímu počtu nových bezpečnostních rizik (mezi něž se řadí především terorismus, kybernetická kriminalita, organizovaný zločin s mezinárodním rozsahem, atd.) stává otázka zajištění vnitřní bezpečnosti velmi diskutovanou, a to jak na vnitrostátní tak i na evropské a mezinárodní úrovni. ${ }^{2}$ Ve stínu řady tragických událostí, $\mathrm{k}$ nimž došlo $\mathrm{v}$ posledních zhruba dvou desítkách let nejen v Evropě, ale i v jiných částech světa, se vlády jednotlivých zemí snažî nalézt adekvátní reakce na tyto negativní projevy globalizace, které by jim umožnily nová bezpečnostní rizika, když už ne zcela eliminovat, tak alespoň v maximální možné míře minimalizovat. ${ }^{3}$

Do množiny právních prostředků nezbytných k zajištění vnitřního pořádku a bezpečnosti lze nepochybně zahrnout i vybavení př́slušných orgánů veřejné moci odpovídajícími pravomocemi v oblasti oprávnění k fyzickému zásahu do práv a svobod osob, které se uskutečňují v podobě realizace tzv. „bezprostředních zásahư‘ ${ }^{4}$ Jedině tak mohou tyto

1 Srov. FILIP, J. Nástin problému bezpečnosti státu z pohledu Ústavního práva. In: DANČÁK, B. a V. ŠIMÍČEK (eds.). Bezpečnost České republiky - právni aspek.ty situace po 11. zárĭ 2001. 1. vyd. Brno: MU, 2002, s. 11

2 „Mezi di̊sledky teroristických útokĩ z 11. zárü 2001 lze zaradit i posun diskuse o reálném obroženi demokratického systému organizovaným zločinem a politickým terorismem z.prostredi odborných krubu do prostredi nejšriři veřejnosti, diskuse, jejímž obsahem jsou úvahy o prostredcich zpissobilých reálnè čelit stávajicím výzvám obrožujicím vnitřni mír a demokratická společenstvi, úvaby o tom, do jaké miry pritom lze akceptovat i takové postupy, jež by mobly zúzit stávajici míru ochrany základnich práv“. MUSIL, J., J. ŠVESTKA a P. HOLLÄNDER. Bezpečnostní výzvy a omezení základních práv v postmoderní realitě. In: DANČÁK, B. a V. ŠIMÍČEK (eds.). Bezpečnost České republiky právni aspekty situace po 11. zárí 2001. 1. vyd. Brno: MU, 2002, s. 94.

3 „Je obvyklé v této souvislosti poukazovat na fakt, že v modernim globalizovaném svétè se bezpečnostni rizilea vnèjsi i vnitrni velmi prolínaji a musi být vnímána ve vájemném kontextu. To platí zejména o situaci, kedy rada státu re ré vnitřní bezpečnostni problémy, keteré mají piovod v zabranič č maji určité zabranični souvislosti, jako je organizovaný zločin a terorismus s mezinárodním zapojením, problémy souvisejici s migraci a možnostmi volného pobybu osob (včetně pachateli

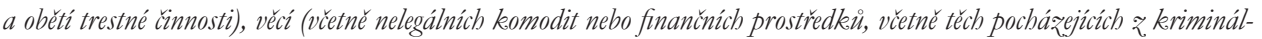
nich zdrojui), a kdy jsou aktuálni tzv. asymetrické hrozby, vyznačujici se tím, že misto brozby konvenčního vojenského útoku hrozí v podstatě keriminální činnost zaměrená na citlivá mista infrastruktury, státu č společnosti". VANGELI, B. Vnitřní bezpečnostní politika České republiky s důrazem na oblast vnitřního pořádku a bezpečnosti. In: HRUBEŠ, M. (ed.). Analyza policy. 1. vyd. Brno: MU, 2011, s. 120.

4 „Bezprostredni zásah je správni úkon k odvráceni nebezpeči, které bezprostredně obrožuje právem chránèné zájmy. Vykonavatel verejné správy fy zicky zasabuje do právnich pomèru osob, které toto obroženi vyvolaly, nebo tretich osob a omezuje je v jejich právech". HENDRYCH, D. et al. Správní právo. Obecná cást. 9. vyd. Praha: C. H. Beck, 2016, s. 187. 
orgány poskytovat dostatečnou ochranu tzv. „policejním statkům“. 5, 6

Realizace bezprostředních zásahů (stejně jakož i ostatních forem faktických úkonů, jež sice nemají povahu přímého fyzického donucení, nicméně jejich realizace je zpravidla taktéž spojena se zásahem do práv a svobod osob, vưči nimž jsou uplatněny), představuje v rámci výkonu veřejné správy nepochybně ultima ratio, tedy nejzazší možnost, spočívající v aplikaci těch nejintenzivnějších prostředků státního donucení, které jsou orgány veřejné správy oprávněny vưči adresátům svého působení uplatnit v situaci, kdy mírnější prostředky nejsou či by zjevně nebyly k dosažení stanoveného cíle dostačující.

Jelikož bezprostřední zásahy náleží mezi takto citelné prostředky veřejně-mocenského donucení, je tato forma realizace veřejné správy v demokratickém právním státě uplatňována pouze za účelem ochrany těch nejvýznamnějších zákonem chráněných zájmů, jakými jsou život, zdraví, majetek či osobní svoboda jednotlivce. Z tohoto důvodu je třeba rozsah oprávnění k jejich realizaci, která bývají zpravidla legislativně řešena prostřednictvím obecných autorizačních doložek ${ }^{7}$ či speciálních zákonných zmocnění, ${ }^{8}$ omezit ještě dalšími zákonnými prostředky. Těmi jsou jednak výslovná omezující ustanovení vyjádřená v jednotlivých zvláštních zákonech a dále pak právní zásady a principy, mezi kterými se ve vztahu k dané problematice jako nejvýznamnější jeví zásada př́iměřenosti.

5 „Mezi tyto statky jsou tradičně razeny ochrana státu, veřejná bezpečnost, bezpečnost osob a majetku, klid, mravnost, veřjné zdravi; jejich okeruh se však stále rozruistá, a podat úplný výcet neni s obledem na dynamiku dosti dobře možné a ostatně ani účelné. MATES, P., J. ŠKODA a F. VAVERA. Verejné sbory. 1. vyd. Praha: Wolters Kluwer ČR, 2011, s. 2.

6 Vymezením policejních statků se zabývala již prvorepubliková právní věda. Tehdejší literatura v této souvislosti uvádí několik neurčitých pojmů, jakými je např́íklad veřejný zájem, veřejné dobro či veřejná mravnost. S vědomím nutnosti výkladu těchto pojmů Slovník veřejného práva československého uvádí okomentovaný názor tehdejšího Nejvyššího správního soudu. „Verejný pokoj a rád znamená jednak soubrn právních norem a norem etických a společenských, jejichž zachováni podle dočasně panujücích obecných názori je podmínkou klidného a sporádanébo soužití, jednak stav společnosti onèm normám odpovidajici". V definici této zachycen je právě jak onen element normativního rázu, jenž zastoupen jest v obratu zde vykládaném slovem , rád“", tak i element rázu statusovébo, jenž odpovidá použitému żde slovu „pokoj", nad to pak tento poslednèjši výraz zákonný je vyložen ještě i v tom smèru, že musi jút v̌̌dy o ochranu klidnébo a sporádanébo soǔ̌ití. Přri pojmech veřejný rád, klid apod. nejde o nic nejuristickébo, metajuristickébo, prirozenoprávního; právní rád recipuje pro sebe názory společenské a etickeé. HÁCHA, J., J. HAVELKA, J. HOETZEL a K. LAŠTOVKA. Slovnik verejného práva československého. Svazek III. Brno: Polygrafia, 1934, s. 165.

7 Obecné zákonné zmocnění je legislativně technicky tvořeno tak, že se do hypotézy právní normy vsunují výrazy (neurčité právní pojmy) jako např. „,veřejný pořádek“, „bezpečnost“, atd. Tyto výrazy vyjadřují ve zkratce stav, který existuje, jestliže jsou v podstatě dodržena pravidla chování lidí, která sice nejsou výslovně a podrobně vyjádřena v právní normě, jsou však právně závazná, nebot’ je nutné je dodržovat podle obecného přesvědčení lidí v určitém čase a v určitém místě. Srov. LUKEŠ, Z. Základy bezpečnostního práva. Praha: ACADEMIA, 1971, s. 78.

8 „Speciálni zákonné żmocnèni je konstruováno tak, že v prǒslušné právni normè, z. niž se toto żmocnèni odvozuje, je bypotéza formulována relativnè určitě (konkéétnè), jednoznačnè nebo taxativnè, a tím je uvážení prí její aplikaci ponechán úzké prostor. Cím konkrétnèjš́ je bypotéza práuni normy, tím užsí je prostor pro uváženi pri aplikaci právni normy a snazši je koneckoncu i prezkoumání, żda na jedné straně byla správnè splnèna prǐslušná právni povinnost, a na drubé straně, zda byl správný postup orgánu státni správy v prípadě nutnosti vymáháni této povinnosti“. LUKEŠ, Z. Základy bezpečnostního práva. Praha: ACADEMIA, 1971, s. 80. 
$\mathrm{Na}$ druhou stranu nezákonná nečinnost spočívající v neuskutečnění bezprostředního zásahu může mít za následek trvání protiprávního jednání, v jehož důsledku hrozí nebezpečí vzniku závažné újmy či škody. Proto jsou zákonná ustanovení obsahující oprávnění k realizaci bezprostředních zásahů náležejících do pravomoci Policie České republiky (dále jen „policie“) doplněna o pozitivní vyjádření obecné zásady iniciativy, která př́slušníkům policie zakládá povinnost postupovat v př́ípadě ohrožení nebo porušení vnitřního pořádku a bezpečnosti, jehož odstranění spadá do úkolů policie, zákonem předpokládaným způsobem, tj. konat z tzv. „úřední povinnosti“.

Otázka optimálního vyvážení zásady přiměřenosti a zásady iniciativy ve vztahu k plnění úkolů policie je ovšem spojena nejen s reakcí na ty nejzávažnější druhy kriminality zmíněné na začátku tohoto úvodu, ale i s postupem policie vưči pachatelům ostatní trestné činnosti či dokonce přestupkového jednání. V těchto případech je otázka adekvátního př́stupu ze strany policie vůči adresátům svého působení snad ještě diskutovanější, nebot' uplatnění represivních prostředků spojených s omezením práv a svobod osob se v př́padě méně závažného protiprávního jednání na první pohled často jeví jako neopodstatněné. Nicméně je třeba si uvědomit, že zákonné uplatnění moci (např́íklad v podobě zásahů represivních složek) ve všech případech na jedné straně svobodu omezuje, ale na druhé straně ji zároveň zabezpečuje. ${ }^{9,10}$

$\mathrm{V}$ rámci předkládaného př́spěvku se pokusím nejen o řešení některých teoretických otázek spojených s danou problematikou, ale hodlám se zabývat též analýzou vybraných př́padů z aplikační praxe, na nichž se pokouším demonstrovat úskalí při hledání kompromisu mezi uplatněním zásady přiměřenosti a zásady iniciativy v rámci reálného fungování policie. Cílem předkládaného příspěvku je vedle uplatnění teoretického přístupu ke zvolené problematice též přiblížení jejího přesahu do oblasti aplikační praxe.

\section{Problematika nezákonné nečinnosti a odpovědnosti za škodu vzniklou v souvislost $\mathrm{s}$ neuskutečněním bezprostředního zásahu náležejícího do pravomoci Policie České republiky}

Veškeré orgány veřejné správy jsou povinny při výkonu své činnosti postupovat v souladu s právními př̀edpisy. ${ }^{11}$ Takové pojetí veřejné správy odpovídá naplnění ústavní zásady

9 Srov. HOLLÄNDER, P. Filozofie práva. 2. vyd. Plzeň: Aleš Čeněk, 2012, s. 161.

10 „Na jedné straně predstavuje bezpečnost, predev̌̌im pak individuálni bezpečnost, jedno z chránèných práv. Na drubé

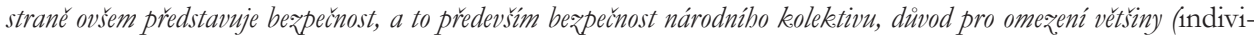
duálních pozn. aut.) chránèných práv“. SCHORM, V. A. Několik poznámek k omezení práv a svobod zaručených Evropskou úmluvou o lidských právech z důvodu bezpečnosti. In: DANČÁK, B. a V. ŠIMÍČEK (eds.). Bezpečnost České republiky - prárni aspekty situace po 11. zárí 2001. 1. vyd. Brno: MU, 2002, s. 83.

11 Srov. \ 2 odst. 1 zákona č. 500/2004 Sb., správního řádu, ve znění pozdějších předpisů (dále jen „správní rád“). 
legality. ${ }^{12}$ Zásada legality neslouží ovšem pouze k omezení aktivní činnosti orgánů veřejné moci v prŕpadě, kdy tato činnost přesáhne zákonný rámec jejich pravomoci, ale zakládá též povinnost nebýt pasivní v př́padě, kdy zákon těmto orgánům přikazuje právem předvídaným způsobem jednat z úřední povinnosti, což v souvislosti s úkony prováděnými v rámci vedení správního řízení odpovídá zásadě oficiality. ${ }^{13}$ Ve vztahu k faktickým úkonům realizovaným policií je zásada oficiality označována jako zásada iniciativy. Zásada iniciativy z tohoto hlediska představuje jednu z dílčích složek zásady legality, ${ }^{14}$ která stojí ve vzájemné protiváze k zásadě zdrženlivosti, jež představuje jednu z komponent zásady přiměřenosti.

Obecnou výjimku z bezpodmínečné vázanosti zásadou oficiality (iniciativy) tvoři př́ipady, kdy zákon dává úředním osobám možnost rozhodnout o dalším postupu v podobě tzv. „uvážení jednání“, které představuje jednu ze dvou forem správního uvážení. ${ }^{15} \mathrm{~V}$ takovém případě se př́islušná úřední osoba může (za splnění ostatních podmínek stanovených pro aplikaci správního uváženî ${ }^{16}$ rozhodnout, zda zákonem daný postup provede či nikoliv. Ve vztahu k faktickým úkonům vykonávaným policií jsou specifické zákonné výjimky omezující působnost zásady iniciativy upraveny v \ 10 odst. 4 zákona č. 273/2008 Sb., o Policii České republiky, ve znění pozdějších předpisů (dále jen „zákon o policii“‘).

Problematika nezákonné nečinnosti bývá obecně spojována s průtahy v rámci formalizovaného řízení. V oblasti veřejné správy se jedná především o nevydání správního rozhodnutí ve stanovené lhůtě. ${ }^{17}$ Nicméně je třeba zdůraznit, že nezákonná nečinnost

12 Srov. čl. 2 odst. 3 Ústavního zákona č. 1/1993 Sb., Ústavy České republiky, ve znění pozdějších předpisů (dále jen „Ústava“) a čl. 2 odst. 2 Usnesení předsednictva ČNR č. 2/1993 Sb., o vyhlášení Listiny základních práv a svobod jako součásti ústavního pořádku České republiky, ve znění pozdějších předpisů. (dále jen „Listina“).

13 Zásada oficiality se ve správním řízení uplatňuje souběžně s alternativní zásadou dispoziční. Působení zásady oficiality ve správním řízení spočívá v tom, že správní orgán v řízení postupuje z moci úřední a jeho běh je nezávislý na vưli účastníků řízení. Srov. SKULOVÁ, S. et al. Správní právo procesní. Plzeň: Aleš Čeněk, 2008, s. 79.

14 „O principu legality mluvime tehdy, kedy je právnè stanovena povinnost k jednání. Podle principu legality jsou tedy beapečnostni orgány a jejich aparát pri existenci určitébo stavu (trestné činnosti) povinny jednat určitým zpuisobem“. LUKEŠ, Z. Základy beapečnostního práva. Praha: ACADEMIA, 1971, s. 83-84.

$15 \mathrm{~V}$ př́ípadě uvážení jednání je př́slušná úřední osoba oprávněna se na základě zákona rozhodnout o tom, zda zákonem daný postup uplatní či nikoliv. V této souvislosti se zpravidla musí nejprve vypořádat s výkladem neurčitých právních pojmů, a to s cílem vyhodnotit, zda daná situace dopadá na obsah pojmu, při jehož naplnění jí zákon přiznává příslušná oprávnění. Srov. SKULOVÁ, S. Správni uvážení. Základní charakteristika a souvislosti pojmu. 1 vyd. Brno: MU, 2004, s. 62.

16 „Správni uvážení je v prvé radě vždy limitováno principy vyplývajicimi z ústavního pořádku Ceské republiky; z nichž lze vyvodit, že i tam, kde vydáni roz̧hodnuti qávisi toliko na uváženi správníbo orgánu, je tento orgán omez̧en zákaz̧em libovile, prǐkazem rozhodovat v obdobných vécech obdobně a ve stejných vécech stejně (rüznost roz̧odováni ve stejných či obdobných věcech mưže být právě projevem ústavně reprobované libovile), tj. principem rovnosti, zákazem diskriminace, príkazem zachovávat lidskou dìstojnost, jakož i povinností výslovné uvést, jaká keritéria v rámci své úvahy použil, jaké dükazni prostredky si opatrill, jaké dikazy provedl a jak je hodnotil, a k jakým skutkovým a právnim závéruim dospèt. Usnesení Nejvyššího správního soudu ze dne 23. 3. 2005, č. j. 6 A 25/2002-42.

17 Srov. např. HENDRYCH, D. et al. Správni právo. Obecná část. 8. vyd. Praha: C. H. Beck, 2012, kapitola XLII. 
se může vyskytnout $\mathrm{v}$ souvislosti s realizací jakékoliv právní formy činnosti orgánů veřejné správy, tedy i v souvislosti s neuskutečněním bezprostředního zásahu, na jehož realizaci existuje právní nárok vyplývající z obecné právní zásady veřejné správy jako služby občanům, ${ }^{18}$ která je dále konkretizována v rámci jednotlivých právních předpisů. ${ }^{19}$ Zásada iniciativy je ve vztahu k činnostem, jejichž realizace náleží do pravomoci policie, pozitivně vyjádřena v \ 10 zákona o policii, který př́́slušníkům policie (dále jen „policistům“) a zaměstnancům zařazeným v policii (dále jen ,zaměstnancům policie“) ve službě (a policistům i mimo službu) ukládá povinnost provést úkon ${ }^{20,21} \mathrm{v}$ rámci své pravomoci, popř́padě učinit jiná opatření vedoucí k odstranění ohrožení nebo porušení vnitřního pořádku a bezpečnosti, jehož eliminace spadá do úkolů policie. ${ }^{22}$ Zásada iniciativy je nicméně dílčím způsobem upravena i v následujícím ustanovení $\int 11$ písm. b) zákona o policii, které je však jako celek primárně věnováno zásadě přiměřenosti. ${ }^{23}$ Zde se uvádí, že rozhodnutím policisty (nebo zaměstnance policie) neprovést úkon nesmí osobám, jejichž bezpečnost je ohrožena, vzniknout bezdůvodná újma.

Důvod, proč zákonodárce upravil povinnost k iniciativě ve dvou různých ustanoveních (s rozdílnými názvy i obsahem), není dle mého názoru zcela zřejmý. Osobně se domnívám, že obsah ustanovení $\int 11$ písm. b) by lépe odpovídal předmětu úpravy předchozího \ 10 zákona o policii. ${ }^{24}$

Jeden z typových znaků bezprostředních zásahů spočívá ve skutečnosti, že se v jejich př́padě jedná o bezprostřední reakci na aktuálně hrozící nebezpečí, a tudíž zde nejsou,

18 Státní moc slouží všem občanům a veřejná správa je službou veřejnosti. Srov. čl. 2 odst. 3 věta první Ústavy a $\ 4$ odst. 1 věta první správního řádu.

19 Policie slouží veřejnosti. Jejím úkolem je chránit bezpečnost osob a majetku a veřejný pořádek, předcházet trestné činnosti, plnit úkoly podle trestního řádu a dalš́ úkoly na úseku vnitřního pořádku a bezpečnosti svěrené jí zákony, př́mo použitelnými předpisy Evropské unie nebo mezinárodními smlouvami, které jsou součástí právního rádu. Policista je povinen dbát, aby jeho rozhodnutím neprovést úkon nevznikla osobám, jejichž bezpečnost je ohrožena, bezdůvodná újma. Srov. $\ 2$ a \11 písm. b) zákona o policii.

20 „Úkoon je jednání, présně vymezené pravomocemi podle právního rádu, podle zákona o policii, ale téžn napr. služebním zákonem u policistui jako subjektu oprávnèných provádèt tuto činnost. Provedeni úkonu nebo jinébo opatrení je nutné zhodnotit v návaznosti na konkrétni situaci. Policista nebo zamèstnanec policie z.hodnotípotrébu subsidiärníbo či alternativního

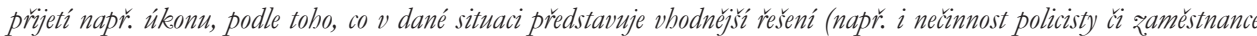
policie z divvodu uklidnèní situace prì konkrétni situaci), které predejde nebo odstraní negativni výsledek". ŠKODA, J., F. VAVERA a R. ŠMERDA. Zákon o policii s komentárem. Plzeň: Aleš Čeněk, 2009, s. 69.

21 Zaměstnanci policie jsou povinni postupovat v souladu se zásadou iniciativy pouze v pracovní době.

22 Srov. $\ 10$ odst. 1 zákona o policii.

23 Což vyplývá již ze samotného názvu tohoto ustanovení. Viz nadpis \11 zákona o policii.

24 Pokud jde o samotný název $\int 10$ zákona o policii (,iniciativa“), zde je vhodné zmínit názor autorů komentáře $\mathrm{k}$ tomuto zákonu, kteří uvádí, že „Toto ustanovení je nažáno v určitém rozporu s jeho obsahem, jelikož se nejedná o iniciativu v pravém slova smyshu (iniciativa je impulz smèrujicí k aktivité [z latinského podnèt, popud, impulz smèrujicí k. určité aktivitè], ale o povinnost (logickou, vžbledem k posláni policie), cožje také v normativnim textu uvedeno". ŠKODA, J., F. VAVERA a R. ŠMERDA. Zákon o policii s komentárem. 2. vyd. Plzeň: Aleš Čeněk, 2009, s. 64. 
na rozdíl od procesních úkonů, zákonem stanoveny žádné lhůty pro jejich realizaci. ${ }^{25}$ To znamená, že v prrípadě nastoupení zákonem předvídaných podmínek, tj. bezprostředního ohrožení zpravidla pozitivně vyjádřených zákonem chráněných zájmů, je třeba v souladu s naplněním zásady iniciativy provést zásah okamžitě, tj. bez zbytečného odkladu. $\mathrm{V}$ př́padě, že zásah není proveden bez zbytečného odkladu, jedná se o porušení zásady iniciativy, které má současně podobu nezákonné nečinnosti, jež mưže spočívat bud' v absolutním neuskutečnění zásahu anebo v neuskutečnění zásahu v přiměřené lhưtě.

Základním prostředkem ochrany před nezákonným působením a tedy i před př́ipadnou nezákonnou nečinností je $\mathrm{v}$ př́padě policie stížnost, prostřednictvím jejíhož uplatnění může každý upozornit na nedostatky v činnosti policejního útvaru nebo konkrétního policisty. ${ }^{26} \mathrm{~V}$ případě, že je stížnost po jejím prověření př́slušným orgánem ${ }^{27}$ vyhodnocena jako důvodná, zavazuje policii k náhradě škody, pokud nějaká v souvislosti s nezákonnou nečinností (či naopak činnostî) policie vznikla.

Odpovědnost státu za škodu vzniklou v souvislosti s činností jeho orgánů představuje výrazný demokratizační prvek, který se v současné moderní plně rozvinuté podobě objevuje $\mathrm{v}$ našem právním řádu poměrně nedávno. Nutno ovšem dodat, že kořeny tohoto institutu, tedy první snahy o regulaci této problematiky na zákonné úrovni, sahají do vzdálenější minulosti ${ }^{28}$ a naprŕíklad prvorepubliková právní věda již zcela otevřeně zdůrazňovala potřebu účinné ochrany občanů před nezákonnými projevy veřejné moci, přičemž slovy J. Hoetzela „Smysl právního rádu moderního státu je predevšim v tom, aby se občanovi dostalo ochrany proti úradìm". ${ }^{29}$

Nárok na náhradu škody vzniklé v souvislosti s činností (či nečinnostî) policie jakožto orgánu státní správy upravuje vedle obecné právní úpravy, kterou je zákon č. 82/1998 Sb., o odpovědnosti za škodu způsobenou při výkonu veřejné moci rozhodnutím nebo nesprávným úředním postupem a o změně zákona České národní rady č. 358/1992 Sb., o notáŕích a jejich činnosti, ve znění pozdějších předpisů (dále jen ,zákon o odpovědnosti za škodu způsobenou při výkonu veřejné moci“`), též zvláštní právní úprava, kterou představuje zákon o policii. ${ }^{30} \mathrm{Jak}$ ovšem uvádí D. Hendrych: „Tato zulástní qákonná úprava

25 „Tyto úkony pro svoji neodkladnost nejsou uskutečnovány jinak obvyklým procesním postupem, respektujicím v̌sechna

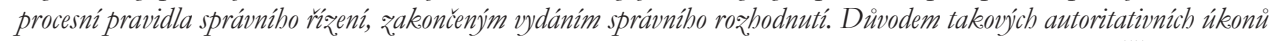
je typicky neodkladná potreba ochrany života, zdravi, majetku a veréjnébo porádku“. Rozsudek Nejvyššího správního soudu ze dne 30. 4. 2008, č. j. 4 Aps 5/2007-53.

26 Srov. $\int 97$ odst. 1 zákona o policii.

$27 \mathrm{~V}$ praxi se bude nejčastěji jednat o Odbor vnitřní kontroly.

28 Existence právních předpisů upravujících problematiku odpovědnosti za škodu způsobenou v souvislosti s výkonem veřejné moci bývá zpravidla mylně spojována až s moderním demokratickým právním státem. Nicméně první právní předpisy regulující tuto problematiku, jakým byl například dvorský dekret č. 758/1806 sb. zák. soud., lze vysledovat již v období tzv. policejního státu. Srov. MATES, P. a J. SEVERA. Odpovédnost státu za výkon verejné moci. 1 vyd. Praha: Leges, 2014, s. 7.

29 HOETZEL, J. Ceskoslovenské správni právo. Cást všeobecná. Praha: Melantrich, 1934, s. 375.

30 Viz $\int 95$ zákona o policii. 
čini v praxi často interpretačni potí̌̌e, nebot'zjejího obsabu neni zcela zjevné, zda se jedná o autonomni zákonnou úpravu nezávislou na zákonu o odpovédnosti za škodu zpuisobenou pri výkonu verejné moci, č je tato úprava (zákon o policii) k. zákonu o odpovédnosti za škodu zpiosobenou prí výkonu veřjné moci v pomèru speciality, cožje pravdèpodobnèjšc “ ${ }^{31}$ Podobný názor zastávají i autoři komentáře k zákonu o odpovědnosti za škodu způsobenou při výkonu veřejné moci. ${ }^{32}$ Jinou systematiku do této problematiky vnáší svým názorem P. Mates a J. Severa, když uvádějí, že úpravou podle $\int 95$ zákona o policii se řídí úkony učiněné dle $\int 2$ tohoto zákona (tedy bezprostřední zásahy, jakož i ostatní faktické úkony). Naopak při plnění úkolů policie v postavení orgánu veřejné správy (podle jednotlivých zvláštních zákonů) je namístě postup podle zákona o odpovědnosti za škodu zpo̊sobenou při výkonu veřejné moci. ${ }^{33}$

Zde je ovšem třeba rríci, že zákon o policii ve svém \95 věnovaném náhradě škody, na rozdíl od \ 13 odst. 1 zákona o odpovědnosti za škodu zpơsobenou při výkonu veřejné moci, s náhradou škody vzniklé v souvislosti s nezákonnou nečinností policie výslovně nepočítá.34 Dále je třeba zohlednit též skutečnost, že v př́padě zákona o odpovědnosti za škodu způsobenou při výkonu veřejné moci je z povahy věci předmět právní regulace, zvláště co se týká postupu při uplatnění nároku na náhrady škody, upraven podrobněji. Proto se domnívám, že v případě škody či újmy vzniklé v souvislosti s nezákonnou nečinností policie, spočívající v neuskutečnění bezprostředního zásahu, na jehož realizaci existoval právní nárok, je namístě vycházet z již zmíněného vztahu speciality př́slušných ustanovení vyjádřených v $\int 95$ zákona o policii k obecné právní úpravě reprezentované zákonem o odpovědnosti za škodu způsobenou při výkonu veřejné moci.

$\mathrm{V}$ př́padě nezákonné nečinnosti ze strany policie (stejně jakož i v př́padě nezákonného zásahu či rozhodnutî) je dále možné se domáhat soudní ochrany v rámci správního soudnictví. Ochrana před nezákonnou nečinností ve smyslu \ 4 odst. 1 písm. b) zákona č. 150/2002 Sb., soudního řádu správního, ve znění pozdějších předpisů (dále jen „soudní rád správni“") je koncipována primárně k ochraně před nezákonnou nečinností $\mathrm{v}$ př́padě nevydání správního rozhodnutí $\mathrm{v}$ rámci správního řízení v zákonem stanovené lhůtě. ${ }^{35}$ Nicméně judikatura Nejvyššího správního soudu v této souvislosti

31 Srov. HENDRYCH, D. et al. Správní právo. Obecná ćást. 8. vyd. Praha: C. H. Beck, 2012, s. 615-616.

32 „Podle zákona č. 82/1998 Sb., o odpovédnosti za škodu zpiobobenou prí výkonu verejné moci rozhodnutím nebo nesprávným úredním postupem a o żmèně zákona Ceské národni rady č. 358/1992 Sb., o notárüch a jejïh činnosti, ve znèní pozdèjšçch predpisu nelze postupovat tam, kede je odpovédnost státu za škodu založena a upravena zuláštním zákonem“. VOJTEK, P. a V. BIČÁK. Odpovédnost za škodu při výkonu verejné moci. Komentár. 4. vyd. Praha: C. H. Beck, 2017, s. 12.

33 Srov. MATES, P. a J. SEVERA. Odpovédnost státu za výkon veřejné moci. 1 vyd. Praha: Leges, 2014, s. 37.

34 V \ 95 odst. 1 zákona o policii se uvádí, že stát je povinen nahradit škodu zpo̊sobenou policií v souvislosti s plněním úkolů policie, což evokuje spíše dojem odpovědnosti z aktivní činnost policie. Využitî tohoto ustanovení pro uplatnění nároku na náhradu škody způsobené nečinností policie by tak vyžadovalo značně extenzivní výklad jeho obsahu.

35 Srov. $\int 79$ odst. 1 soudního řádu správního. 
zaujímá stanovisko, že nezákonným zásahem ${ }^{36}$ ve smyslu $\int 4$ odst. 1 písm. c) soudního rádu správního může být i nezákonná nečinnost, a to v případě, že takový zásah měl být uskutečněn. ${ }^{37} \mathrm{~V}$ případě nezákonné nečinnosti spočívající v neuskutečnění bezprostředního zásahu tedy soud postupuje podle $\int 82$ a násl. soudního řádu správního. ${ }^{38}$ Určení toho, že neuskutečněním zásahu byl porušen zákon, má význam především pro případné následné uplatnění nároku na náhradu škody, kdy nezákonnost postupu představuje jednu ze tří podmínek pro vznik odpovědnosti státu. ${ }^{39}$

$\mathrm{V}$ neposlední řadě je třeba říci, že případná nečinnost policejního orgánu v případě, že si situace vyžaduje realizaci bezprostředního zásahu, přičemž v důsledku jeho neuskutečnění dojde k vážným následkům na životě, zdraví, majetku či právech dotčených osob může mít pro příslušné policisty i trestněprávní důsledky. S ohledem na jejich veřejně-mocenské postavení v podobě úředních osob by se v tomto př́ípadě s největší pravděpodobností jednalo o naplnění skutkové podstaty trestného činu maření úkolu úřední osoby z nedbalosti, ${ }^{40,41}$ nicméně v závislosti na konkrétní situaci přicházejí v úvahu i jiné

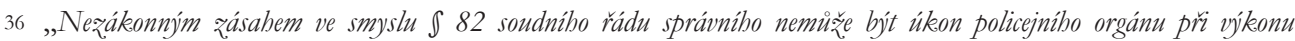
puisobnosti orgánu činnébo v trestním rízení. Zásabem podrobeným prezkoumáni ve správním soudnictví však mĩže být zásah policejního orgánu prĭ výkonu puisobnosti ve verejné správe“. Rozsudek Nejvyššího správního soudu ze dne 28. 4. 2005, č. j. 2 Aps 2/2004-69.

37 „Podminky ř́zeni o žalobě na ochranu pred nezákonným zásabem bliže rozvedl senát Nejvy šš́ho spráaniho soudu v usne-

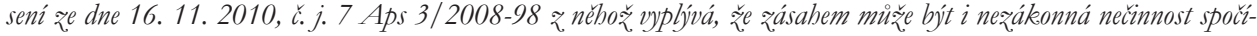

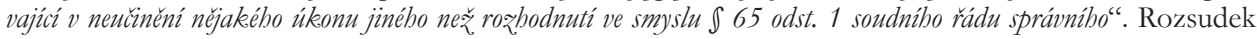
Nejvyššího správního soudu ze dne 28. 1. 2016, č. j. 10 As 236/2015-36.

$38 \mathrm{~V}$ této souvislosti je třeba poznamenat, že Ústavní soud vykládá pojem „zásah orgánu verejné moci do ústavně zaručených základních práv a svobod" tak šroce, že za takový zásah považuje i nečinnost orgánu veřjné moci, jǐ̌ je porušováno základní právo na projednáni véci ,bez zbytečných pritahi̛. Srov. HENDRYCH, D. et al. Správní právo. Obecná část. 8. vyd. Praha: C. H. Beck, 2012, s. 491. Přesto, že zde má Ústavní soud na mysli průtahy ve správním řízení, je pravděpodobné, že v př́padě kdy by v souvislosti s nečinností policejního orgánu spočívající v neuskutečnění bezprostředního zásahu došlo k porušení ústavně zaručeného práva nebo svobody, by se Ústavní soud touto stížností zabýval, to ovšem pouze za předpokladu, že v době podání ústavní stížnosti a v době rozhodování Ústavního soudu o ní by nečinnost (či naopak nezákonný zásah) stále vyvolávala v osobní sféře stěžovatele právní následky. Srov. Usnesení Ústavního soudu ze dne 11. 4. 2001, sp. zn. I. ÚS 690/2000.

39 Obecně lze vysledovat tři podmínky vzniku odpovědnosti státu za výkon veřejné moci.

a) rozhodnutí bylo zrušeno jako nezákonné či bylo určeno, že zásah byl nezákonný anebo došlo k nezákonné nečinnosti,

b) existuje škoda či újma,

c) existuje zde přícinná souvislost mezi nezákonným rozhodnutím, zásahem nebo nečinností a vzniklou škodou či újmou. Srov. MATES, P. a J. SEVERA. Odpovédnost státu za výkon verejné moci. 1 vyd. Praha: Leges, 2014, s. 34.

40 Srov. \330 zákona č. 40/2009 Sb., trestního zákoníku, ve znění pozdějších předpisů (dále jen „trestní zákoník").

41 „Zmarením duiležitébo úkolu ve smyslu $\int 330$ odst. 1 trestního zákoniku se rozumi také porušeni povinnosti oprávnèné úredni osoby projednat správni deliket a roz̧hodnout o nèm v zákonné prekluzivni lhuitě. Proto v prípadè, že oprávnèná úredni osoba zprisobi svou nečinností zánik správni odpovédnosti konkétnich osob za takový delikt, ląe vici ni vyvodit trestni odpovédnost za trestný čin mařeni úkolu úredni osoby z.nedbalosti podle $\int 330$ trestníbo zákoníku“. Rozsudek Nejvyššího soudu ČR ze dne 29. 1. 2013, sp. zn. 8 Tz 97/2012. Jak již bylo výše řečeno, nečinnost v př́ipadě neuskutečnění rozhodnutí lze analogicky vztáhnout také na neuskutečnění zásahu. 
právní kvalifikace takového jednání. ${ }^{42}$ Tím ovšem není dotčeno oprávnění uplatnění nároku na náhradu škody podle obecného ${ }^{43}$ či zvláštního právního předpisu. ${ }^{44}$

Pokud jde o praktické využití jednotlivých výše uvedených právních prostředků ochrany před nezákonnou nečinností, které náš právní řád dává v současnosti adresátům veřejně-mocenského působení $\mathrm{k}$ dispozici, zde je třeba říci, že $\mathrm{v}$ prŕpadě nezákonného neuskutečnění bezprostředního zásahu, vzhledem k výše zmíněné povaze této formy realizace veřejné správy, spočívající jak již bylo řečeno v reakci na bezprostřední, zpravidla časově úzce ohraničené ohrožení či porušení zákonem chráněného zájmu, žádný z těchto prostředků (stejně jako v prípadě nezákonné realizace bezprostředních zásahů) neposkytuje okamžitou ochranu proti nezákonné nečinnosti ze strany policie. ${ }^{45}{ }^{46} \mathrm{Z}$ tohoto hlediska má proto $\mathrm{v}$ praxi největší význam již zmíněné uplatnění nároku na náhradu škody či nemateriální újmy vzniklé v důsledku nesprávného úředního postupu dle $\int 13$ zákona o odpovědnosti za škodu způsobenou při výkonu veřejné moci.

Přestože zákon nesprávný úřední postup nijak nedefinuje a tudíž je výklad tohoto pojmu ponecháván na doktríně ${ }^{47}$ a především pak judikatuře, ${ }^{48}$ ze znění $\int 13$ odst. 1 věty druhé a třetí zákona o odpovědnosti za škodu způsobenou při výkonu veřejné moci jasně vyplývá, že nesprávným úředním postupem se rozumí též nezákonná nečinnost. ${ }^{49}$ Pokud jde o pojem úkon, zde se ve vztahu k činnosti veřejné správy jedná o veškeré projevy veřejné správy, které mají povahu právních činností a které zároveň nejsou rozhodnutím ve správním řízení. ${ }^{50}$ Mimo jiné se tedy bude bezesporu jednat o veškeré faktické úkony

42 Např. neposkytnutí pomoci dle $\int 150$ odst. 2 trestního zákoníku.

43 Zákona o odpovědnosti za škodu způsobenou při výkonu veřejné moci.

44 Zákona o policii.

45 Srov. SKULOVÁ, S., L. POTĚŠIL a kol. Prostredky ochrany subjektivnich práv ve verejné správě - jejich systém a efektivnost. 1. vyd. Praha: C. H. Beck, 2017, s. 285.

46 „Pokud Ústavni sond ústavni stížnosti směrujici proti jinému zásabu orgánu veréjné moci vyhoví, „zakáąe tomuto orgánu, aby v porušováni práva či svobody pokračoval a prikéaže mu, aby, pokud je to možné, obnovil stav pred porušenim ". Z toho predevǐim vyplývá, že pojmovým żnakem zminèného ,jiného zásabu" musi být zejména skutečnost, že tento zásah i v době podáni ústavni stižnosti a v době rozhodováni Ústavníbo soudu o ni musi být aktuálni, trn., musív osobni sfére stěžovatele vyvolávat právni následky. Pokud má ,jiný zásab" povabu toliko jednorázovébo zásabu, keterý již v době zahájeni rízueni o ústavni stižnosti skončil, je obnoveni statutu quo ante stejné jako zákaz v pokračováni v porušováni práva (svobody) adresovaný orgánu verejné moci již pojmově vyloučen. Jak Ústavni soud judikoval již v jiném svém roz̧odnutí, zásah orgánu veřejné moci napadený ústavni stǐ̌ností musi být bezprostredni a prítomný (srov. Usneseni Ústavního soudu ze dne 8. 9. 1999, sp. zn. IV. ÚS 122/99), nebot'v opačném prǐpadě by se prezkeum a následné rozhodováni Ústavního soudu stalo čistě akademickeym“. Usnesení Ústavního soudu ze dne 11. 4. 2001, sp. zn. I. ÚS 690/2000.

47 Srov. HENDRYCH, D. et al. Správní právo. Obecná část. 8. vyd. Praha: C. H. Beck, 2012, s. 682.

48 „....nesprávným úredním postupem je každý postup orgánu veřjné moci, který pr̆ jejím výkonu postupuje v rozporu s obecně závaznými práunimi predpisy ă v rozporu se zásadami jejího výkonu“. Nález Ústavního soudu ze dne 8. 7. 2010, sp. zn. Pl. ÚS 36/08.

49 Zákon o odpovědnosti za škodu zpo̊sobenou při výkonu veřejné moci v $\int 13$ odst. 1 uvádí, že v př́padě porušení povinnosti učinit úkon v zákonem stanovené lhůtě, a nestanoví-li zákon pro provedení úkonu žádnou lhůtu ve lhůtě přiměřené, se jedná o nesprávný úřední postup.

50 Srov. HENDRYCH, D. et al. Spráuni právo. Obecná cást. 8. vyd. Praha: C. H. Beck, 2012, s. 440. 
včetně bezprostředních zásahů. Předpokladem pro uplatnění nároku na náhradu škody v souvislosti s nezákonnou nečinností je však skutečnost, že z důvodu nezákonné nečinnosti vznikla škoda či nárok na náhradu nemateriální újmy.

Z právně-teoretického, nicméně i z praktického hlediska se jako poměrně zajímavá jeví otázka odpovědnosti příslušného orgánu za jednání úřední osoby, která v době služby (nebo v pracovní době) provede bezprostřední zásah, který je mimo rámec její pravomoci. Zde mohou nastat v zásadě dvě různé situace. Za prvé může dojít „pouze“ k tzv. „excesu“, což značí situaci, kdy jednání oprávněné úřední osoby vykazuje právní vadu (může se jednat např. o oprávněný zásah, při kterém však dojde k porušení zásady přiměřenosti), nicméně se z materiálního hlediska stále jedná o výkon veřejné správy. $\mathrm{V}$ tomto prípadě ponese odpovědnost za zpơsobenou škodu př́islušný orgán veřejné správy, který může následně po této úřední osobě požadovat regresní úhradu. ${ }^{51}$

Ve druhém případě může dojít k tzv. „nicotnému zásahu“, tedy k jednání, jež uskutečnila osoba, která je obecně k úředním úkonům oprávněna (úřední osoba), nicméně tento konkrétní zásah je uskutečněn zcela mimo rámec její pravomoci, a tudíž nejde o „pouhý“ exces, ale o naprostou nicotnost takového jednání. ${ }^{52}$ Přestože ze správně-právního hlediska není takové jednání jakkoliv relevantní, ${ }^{53}$ vzhledem $\mathrm{k}$ tomu, že jej uskutečnila úřední osoba při výkonu své funkce, bude se z trestněprávního hlediska bezesporu jednat o zneužití pravomoci úřední osoby.

Z judikatury lze dovodit, že to, jestli nicotné jednání úřední osoby půjde k tíži př́íslušného orgánu, u kterého je dotyčná úřední osoba služebně zařazena či jí samotné, závisí na tom, zda se v př́padě jejího postupu jednalo o výkon veřejné moci či nikoliv. Přičemž pro podřazení jednání úřední osoby (ve službě či v pracovní době) pod „výkon veřejné moci“ je rozhodující skutečnost, zda dotyčná úřední osoba jednala výlučně ve svém vlastním soukromém zájmu, a tudíž se jednalo o ryze soukromoprávní akt, ${ }^{54}$ či svým

51 Srov. \16 a násl. zákona o odpovědnosti za škodu.

52 Např. př́slušná úřední osoba oprávněná k projednání přestupku ve správním řízení podle zákona č. 250/2016 Sb., o odpovědnosti za přestupky a řízení o nich, ve znění pozdějších předpisư použije proti osobě, která neuposlechne její výzvy směřující k zajištění řádného průběhu ústního jednání teleskopický obušek, který si na vlastní náklady pořídila.

53 O výkon veřejné moci (ve vztahu k náhradě škody) nejde tam, kde škodu sice způsobila osoba jinak reprezentující stát či územní samosprávný celek, která nicméně svým jednáním zcela vybočila z rámce plnění svých služebních (úředních) povinností, tj. šlo o tzv. nicotnost jejího jednání. VOJTEK, P. a V. BIČÁK. Odpovédnost za škodu prí výkonu veréené moci. Komentár. 4. vyd. Praha: C. H. Beck, 2017, s. 18.

54 „I ve vątabu k policistum, keteř̀ v době trváni služebního pomèru páchali trestnou činnost, judikatura dovodila, že tím neplnili služebni povinnosti plynouci jïm jako tebdejšm př̌slušníkùm Policie České republiky zue zákona č. 283/1991 Sb., o Policii Ceské republiky; jejich jednáni neni možné považovat za plnèni úkoli státu, jestliže jím sledovali výlučně uspokojeni svých vlastnich zájmů a potreb". Rozsudek Nejvyššího soudu ČR ze dne 15. 6. 2011, sp. zn. 28 Cdo 2699/2010. Srov. též VOJTEK, P. a V. BIČÁK. Odpovédnost za škodu prí výkonu veréjné moci. Komentár. 4. vyd. Praha: C. H. Beck, 2017, s. 18-19. 
jednáním sledovala zájem veřejný, poprrípadě jednala $v$ omylu, založeném na přesvědčení, že prostřednictvím svého jednání plní služební (nebo pracovní) povinnosti. ${ }^{55}$

Odpovědnost státu za nesprávný úřední postup spočívající v nezákonné nečinnosti (nebo nezákonné činnosti) policie je odpovědností objektivní, což znamená, že se nepřihlíží k zavinění a policie (potažmo stát) se nemůže této odpovědnosti zprostit. ${ }^{56,57,58} \mathrm{Z}$ tohoto hlediska je podstatná otázka míry zavinění konkrétního policisty (či policistů), nebot' v jeho (či jejich) př́padě se jedná o odpovědnost subjektivní. Otázka subjektivního zavinění je podstatná především v souvislosti s možným uplatněním regresní úhrady vůči policistovi, který svým nesprávným úředním postupem spočívajícím v nesprávném rozhodnutí přivodil odpovědnost bezpečnostního sboru.

Z hlediska zavinění může k nezákonné nečinnosti spočívající v prodlení zásahu dojít jednak z důvodů nezávislých na vưli zasahujícího policisty (např. dopravní kolaps na cestě k místu zásahu) anebo z důvodů majících svůj původ v nesprávném vyhodnocení situace. Otázka rozlišení příčin prodlení je podstatná především z hlediska vyvození odpovědnosti za porušení spočívající v nezákonné nečinnosti a dále př́padného následného uplatnění nároku na náhradu škody v souvislosti s možným uplatněním regresní úhrady vưči policistovi, který svým nesprávným úředním postupem spočívajícím v nezákonné nečinnosti privivodil odpovědnost bezpečnostního sboru.

Závěrem je třeba říci, že vzhledem $\mathrm{k}$ tomu, že $\mathrm{v}$ souvislosti s realizací bezprostředních zásahů dochází zpravidla $\mathrm{k}$ zásahưm do základních práv a svobod osob nemateriální povahy, bude se $\mathrm{v}$ případě náhrady škody, uplatňované v souvislosti s nesprávným úředním postupem při realizaci bezprostředních zásahů uskutečněných ze strany policie ve většině př́padů jednat o nemajetkovou újmu způsobenou nezákonnou nečinnostî nebo naopak nezákonnou činností. Konkrétní postup při jejím uplatnění upravuje zákon a upřesňuje judikatura. ${ }^{59}$

55 „Nelze-li dovodit, že by zaměstnanec, který se snažil vykázat z jím strę̌zeného objektu nepovolanou osobu a následné ji fyzicky bránil v dalšim pobybu v objektu, fyzickým napadením této osoby (byt' naplnilo znaky trestnébo činu) sledoval své osobni nebo jiné zájmy, má jeho jednáni mistní, časový a věcný vątah ke činnosti zamèstnavatele". Rozsudek Nejvyššího soudu ČR ze dne 13. 12. 2005, sp. zn. 25 Cdo 2777/2004.

56 Srov. Rozsudek Nejvyššího soudu ČR ze dne 5. 10. 2016, sp. zn. 30 Cdo 5661/2015.

57 Srov. $\int 95$ odst. 1 věta první zákona o policii.

58 Jediným liberačním důvodem mưže být skutečnost, že osoba, které v souvislosti s činností policie vznikla škoda, svým jednáním oprávněný a přiměřený zákrok (v důsledku kterého škoda vznikla) vyvolala. Srov. \ 95 odst. 1 věta druhá zákona o policii.

59 Např. srov. „Nemajetkovou újmu zpuisobenou nesprávným úredním postupem ve smyslu $\int 13$ odst. 1 věty treti a $\int 22$ odst. 1 věty tretí zákona č. 82/1998 Sb., je třeba turdit a neni-li úspěsnè poprèna anebo nepostačuje-li konstatováníporušeni práva, prižná se za ni zadostiučinèni v penézích“. Stanovisko Nejvyššího soudu ČR ze dne 13. 4. 2011, sp. zn. Cpjn 206/2010. 


\section{Naplnění zásady přiměřenosti při realizaci bezprostředních zásahů uskutečňovaných ze strany Policie České republiky z hlediska teorie a praxe}

Zásada přiměřenosti ${ }^{60}$ působí k ochraně práv osob, vůči nimž směřuje úkon, stejně jakož i práv osob nezúčastněných. V případě bezprostředních zásahů její význam spočívá především v ochraně před neopodstatněně vysokou intenzitou jednání, při němž dochází k zásahu do osobní integrity jednotlivce za použití síly.

Obecné vyjádření této zásady ukládá policistům povinnost postupovat tak, aby žádné osobě v důsledku jejich postupu nevznikla bezdůvodná újma, ${ }^{61}$ a dále pak postupovat tak, aby př́padný zásah do práv a svobod osob, vưči nimž směřuje úkon, nebo osob nezúčastněných, nepřekročil míru nezbytnou $\mathrm{k}$ dosažení účelu sledovaného úkonem. ${ }^{62}$ $\mathrm{V}$ rámci této definice lze vysledovat dvě stěžejní podmínky, jejichž současné naplnění je z hlediska zákonu odpovídajícímu postupu považováno za nezbytné. Konkrétně se jedná o podmínku „nezpůsobit osobám bezdůvodnou újmu“ (a to at’ již v souvislosti s aktivitou, tedy konáním, či naopak nekonáním) a zároveň v př́padě aktivního konání „nepřekročit míru nezbytnou k dosažení účelu sledovaného úkonem“.

Podmínka nepřípustnosti vzniku bezdůvodné újmy osobám v souvislosti s postupem policie ovšem přesahuje samotný rozsah zásady přiměřenosti, a to z toho důvodu, že ke vzniku bezdůvodné újmy na straně civilních osob může v souvislosti s postupem policie dojít i z jiných příčin, nemajících přímou spojitost s otázkou prriměřenosti postupu policie. Bezdůvodná újma může v souvislosti s činností policie vzniknout osobám v důsledku jednak zcela nezákonného postupu policistů (mající často zároveň povahu úmyslného trestného činu, např̀. vydírání nebo přijetí úplatku). Jedná se o situaci, kdy postup policistů vykazuje tak zásadní právní vady, v důsledku nichž se úkon stává nicotným, a tudíž otázka přiměřenosti $\mathrm{v}$ takovém případě již není relevantní. ${ }^{63}$ Mimo to může ze strany policie vzniknout osobám bezdůvodná újma též v souvislosti s nedbalostním jednáním policistů, nemající povahu úkonu (např. dopravní nehoda).

60 „S cílem vyloučit nepriměrenosti nebo jiné právně nekonformni jednáni jsou zásaby do práv a svobod osob propojeny s odpovídajici právni úpravou limitujici tyto zásaby. Zákon o policii tak naplnuje jeden z. esenciálnich znaku demokeratickébo právního státu, kterým je princip priměrenosti. Tento princip vychází zp predpokladu, že opatreni omezujicí základní práva a svobody nesměji svými negativnimi dìsledky presábnout klady, které představuje verejný zájem na tèchto opatrenich". ŠKODA, J., F. VAVERA a R. ŠMERDA. Zákon o policii s komentárem. 2. vyd. Plzeň: Aleš Čeněk, 2009, s. 74.

61 „Za bezduivodnou újmu nelze považovat takovou újmu, jejǐ̌, vanik v duisledku úkonu bud' nebyl rozumně predvidatelný, nebo byl nevyhnutelným dìsledkem (rádnébo) provedeni úkonu, tak aby byly splnèny jeho cíle (smysl), a současně neni tato újma zjevnè nepriměrená væ̧hledem ke cili sledovanému úkonem“. Rozsudek Nejvyššího soudu ze dne 5. 10. 2016, sp. zn. 30 Cdo 5661/2015.

62 Srov. \11 písm. a) a c) zákona o policii.

63 Skutečnost že „nepřiměřenost“ a „,neoprávněnost“ představují dvě zcela odlišné právní vady zásahu, jež zároveň vykazují různou intenzitu nezákonnosti lze dovodit např́iklad z rozsudku Nejvyššího soudu ČR ze dne 5. 10. 2016, sp. zn. 30 Cdo 5661/2015, kde se uvádí, že „Dovolatelka se ztotožñuje se závérem odvolacího soudu, že zákrok policie byl oprávnèný, avšak nikoliv se závèrem, že se jednalo rovnězo o zákrok primèreny". 
Zákon o policii v \ 11 věnovanému přiměřenosti postupu pod písm. b) stanovuje podmínku zákazu vzniku újmy osobě, jejíž bezpečnost je ohrožena v důsledku rozhodnutí policisty neprovést úkon. Tato prríčina vzniku újmy ovšem odpovídá povaze již zmíněné nezákonné nečinnosti, jež z právně-teoretického hlediska nepředstavuje porušení zásady přiměřenosti, ale spíše zásady iniciativy a proto by bylo vhodnější její zařazení do předešlého \10 věnovaného problematice iniciativy.

Právní povinnost „nepřekročit míru nezbytnou k dosažení účelu sledovaného úkonem“ představuje druhou složku zásady přiměřenosti, tak jak je tato zásada vyjádřena $\mathrm{v}$ \ 11 písm. c) zákona o policii. V tomto př́padě se jedná o vyjádření zásady přiměřenosti v její ryzí podobě. Jak uvádí B. Vangeli „v \11 pism. c) zákon stanoví povinnost, keterou lže označit také jako

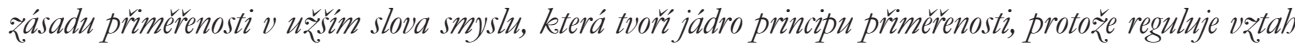
mezi mírou zásahu do práv a svobod osob a účlem sledovaným zákrokem (úkonem) “. ${ }^{64}$ Dle tohoto ustanovení výběr prostředků, jakož i intenzita jejich použití musí z hlediska naplnění zásady přiměřenosti odpovídat intenzitě nebezpečí, které je prostřednictvím realizace úkonu eliminováno, ${ }^{65,66}$ a to s prioritou nekonfliktního řešení situace, jež je vyjádřením zásady subsidiarity represivního prŕstupu ze strany veřejné moci. ${ }^{67} \mathrm{Jak} v$ souvislosti s vymezením zásady „úměrnosti“ (přiměřenosti) policejního zásahu uvádí J. Hoetzel: „Neni-li jiného prédpisu, má se volit

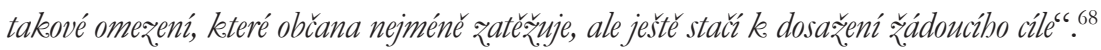

Dle Z. Lukeše je pro naplnění obecných podmínek zásady přiměřenosti nezbytné kladné zodpovězení tří následujících otázek.

a) zda v danou chvíli reálně existuje nebezpečí, které ohrožuje nebo porušuje některý zákonem chráněný zájem, tzn. určení časové přiměřenosti úkonu (jež spočivá v odpovědi na otázku, zda nebezpečí vzniklé z protiprávního jednání bezprostředně hrozí nebo trvá),

b) zda ochrana tohoto zákonem chráněného zájmu náleží do působnosti policie, tedy otázka kompetence konkrétní úřední osoby k realizaci daného postupu v konkrétním př́padě,

c) zda předpokládané následky vzniklé při realizaci zamýšleného opatření budou přiměřné vzhledem $\mathrm{k}$ intenzitě nebezpečí spočívajícího $\mathrm{v}$ ohrožení nebo porušení zákonem chráněného zájmu.

64 VANGELI, B. Zákon o Policii Ceské republiky. Komentár. 2. vyd. Praha: C. H. Beck, 2014, s. 65.

65 Srov. ŠKODA, J., F. VAVERA a R. ŠMERDA. Zákon o policii s komentárem. 2. vyd. Plzeň: Aleš Čeněk, 2009, s. 74 .

66 „Prí rozhodováni o použiti donucovacich prostredkủ nelze odblédnout od toho jak vážný právni zájem je ve bre a jak intenzivné je obrožen “. Rozsudek Nejvyššího správního soudu ze dne 25. 5. 2015, č. j. 6 As 255/2014-42.

67 „Zákrok policie musi být veden zpuisobem priměreným konkrétni situaci tak, aby bylo donuceni policisty uřito jen zpuisobem a v mire bezpečnè dostačujici $k$ dosaženi účlu zákroku, co možná nejvíce mírnicim konfliktni potenciál situace". Rozsudek Nejvyššího správního soudu ze dne 22. 2. 2017, č. j. 2 As 216/2016-92.

68 HÁCHA, J., J. HAVELKA, J. HOETZEL a K. LAŠTOVKA. Slovník veréjného práva československého. Svazek III. Brno: Polygrafia, 1934, s. 168. 
Poslední požadavek na zachování proporcionality úkonu ve vztahu k hrozícímu či trvajícímu nebezpečí uvedený pod písm. c) v sobě zahrnuje dva rozdílné aspekty zásady přiměřenosti.

a) priměřenost volby prostředků, (tedy zodpovězení otázky, zda na základě konkrétních okolností bude např. při zásahu použito mírnějších či důraznějších donucovacích prostředků anebo zbraně, prrípadně který konkrétní donucovací prostředek z dané skupiny bude při zásahu použit),

b) přiměřenost užití zvoleného prostředku (tedy intenzita či způsob použití zvoleného prostředku). ${ }^{69}$

Pokud jde o otázku stanovení míry přiměřenosti u specifické skupiny úkonů, jejichž typovým znakem je skutečnost, že jsou při jejich realizaci použity donucovací prostředky nebo zbraň (bezprostřední zásahy), zde se názory prrijaté v rámci nauky různí. Přestože část autorů zastává názor, že v souvislosti se zásahem, při němž je ze strany policie použito donucovacích prostředků, nesmí osobám, vưči nimž zásah směřuje vzniknout větší škoda, než jaká vznikla či hrozila v důsledku nebezpečí, které bylo prostřednictvím realizace zásahu odvráceno, ${ }^{70}$ lze se setkat i s názorem, ${ }^{71}$ podpořeným závěry judikatury, že obdobně jako $v$ prrípadě obecného institutu nutné obrany zákon v případě použití donucovacích prostředků nenařizuje přísnou proporcionalitu, ale umožňuje prostřednictvím jejich použití způsobit osobě i nepřiměřenou újmu, přičemž hranici staví o něco výše až na úroveň zřejmé, tedy zjevné, očividné nepřiměřenosti. ${ }^{72}$

$\mathrm{V}$ prrípadě realizace bezprostředních zásahů jsou tedy policisté vázáni nejen obecnou zásadou přriměřenosti vyjádřenou v \ 11 zákona o policii, ale též specifickou formou zásady proporcionality, která se vztahuje výlučně $\mathrm{k}$ použití donucovacích prostředků, a která je pozitivně vyjádřena v $\int 53$ odst. 3 písm. a) a b) a odst. 5 zákona o policii. Zde se uvádí, že policista je oprávněn použít donucovací prostředek, který

a) umožní dosažení účelu sledovaného zákrokem a

b) je nezbytný k překonání odporu nebo útoku osoby, proti níž zakročuje.

Současně je však povinen dbát na to, aby při použití donucovacího prostředku nezpůsobil osobě újmu zřejmě nepriměřenou povaze a nebezpečnosti jejího protiprávního jednání.

69 Srov. LUKEŠ, Z. Základy bezpečnostního práva. 1 vyd. Praha: ACADEMIA, 1971, s. 86-87.

70 „Zásah nesmi znamenat vétši škeodu, než predstavuje nebezpeči. Prí stanoveni výše možné újmy stanoví požadavek její primérenosti k povaze a nebeapečnosti protipráuního jednáni". ŠKODA, J., F. VAVERA a R. ŠMERDA. Zákon o policii s komentárem. 2. vyd. Plzeň: Aleš Čeněk, 2009, s. 74 a 208.

71 Viz VANGELI, B. Zákon o Policii České republiky. Komentár. 2. vyd. Praha: C. H. Beck, 2014, 483 s.

72 „Tento prìstup vycházíjednak z védomi objektivni složitosti těch to situaci, která zpio sobuje praktickou nesplnitelnost požadavku prìsné proporcionality, a jednak zpotreby efektivníbo zákroku (obrany), kdy empirická zkušenost dokládá, že aby

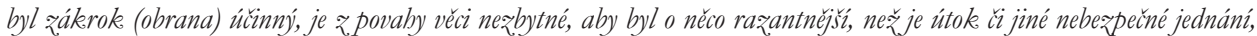
proti nému气̌ je zakročováno“. Rozsudek Nejvyššího soudu ČR ze dne 5. 10. 2016, sp. zn. 30 Cdo 5661/2015. 
Přesto, že jsou př́slušníci bezpečnostních sborů na rozdíl od civilních osob povinni čelit nebezpečí, které má povahu útoku na jejich osobu, ${ }^{73}$ tak jak právní nauka, tak i právně-teoretické analýzy přijaté $v$ rámci Ministerstva vnitra a policie připouštějí možnost jednání policistů (stejně jakož i ostatních příslušníků bezpečnostních sborů) v nutné obraně ${ }^{74,75}$ Dle mého názoru však není možné směšovat jednání policistů učiněné v nutné obraně s realizací bezprostředního zásahu, a to ze dvou důvodů. Za prvé podmínky proporcionality jsou v prrípadě nutné obrany nastaveny odlišně, než jak je tomu v př́padě realizace bezprostředních zásahů. Za druhé zde vyvstává otázka, zda v případě jednání učiněného policistou $\mathrm{v}$ rámci nutné obrany se ještě stále jedná o výkon veřejné moci, či již v tomto př́padě jde o soukromoprávní akt svépomoci. Zodpovězení této otázky má význam především pro stanovení právní povahy předmětného jednání realizovaného policistou (občanská svépomoc nebo výkon veřejné moci) a jeho následné podřazení pod odpovídající právní institut (nutná obrana nebo použití donucovacích prostředků či zbraně), skrze který bude posuzována jeho přiměřenost.

Pokud jde o naplnění podmínky přiměřenosti v prrípadě uplatnění nutné obrany, zde zákon připouští možnost zpo̊sobení škody (útočníkovi) od nulové až po úroveň „,zcela zjevné nepríměřenosti“ $\mathrm{v}$ poměru k povaze a způsobu útoku. ${ }^{76} \mathrm{~V}$ souvislosti s použitím donucovacích prostředků však zákon připouští možnost vzniku pouze ,zřejmě (zjevně) neprriměřené újmy“, což představuje o stupeň nižší intenzitu možného použití síly, jakož i následků z něj vzešlých. Z toho je patrné, že zde existuje zjevná zákonná disproporce mezi požadavkem na stupeň přiměřenosti $\mathrm{v}$ př́padě jednání civilních osob učiněném $\mathrm{v}$ nutné obraně a $\mathrm{v}$ prípadě použití donucovacích prostředků ze strany policie.

Zatímco v současnosti zákon naplněním podmínek pro uplatnění nutné obrany výslovně použití žádného donucovacího prostředku nepodmiňuje, ${ }^{77} \mathrm{v}$ př́padě oprávnění k použití

73 Srov. KUCHTA, J. Nutná obrana. 1 vyd. Brno: MU, 1999, s. 71.

74 „Ani u tèchto speciálnich kategorii osob však patrně není vyloučeno uřití nutné obrany v situacích, kedy nejsou žcela splnèny

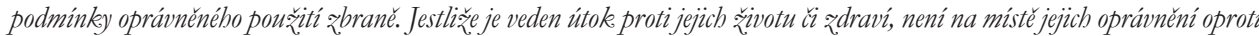
jiným osobám zư̌ovat. Ve svém jednáni by mély být takové osoby omezeny pouze obecnými podminkami nutné obrany, $i$ když by v konkrétnim prĭpadě mèly u sebe z̧brañ. KUCHTA, J. Nutná obrana. 1 vyd. Brno: MU, 1999, s. 72.

75 Např. dle $\int 52$ písm. c) zákona o policii je policista při zákroku oprávněn použít obušek a jiný úderný prostředek, k jehož používání byl vycvičen. Jiné úderné prostředky než které připouští zákon, případně interní akty policie, $\mathrm{k}$ jejichž použití nebyl policista vycvičen (např. boxer) lze použít pouze $\mathrm{v}$ nutné obraně či krajní nouzi. Stejně tak předměty se zcela jiným mechanismem účinku jako jsou např. sekery, kladiva, meče atd., které by z hlediska jejich vlastností bylo možno zařadit spíše mezi zbraně dle $\int 56$ odst. 5 zákona o policii, by bylo možno použít pouze v krajních situacích v režimu použití zbraně dle $\int 56$ odst. 1 písm. a) zákona o policii za podmínek nutné obrany nebo krajní nouze. Srov. Stanovisko odboru bezpečnostní politiky Ministerstva vnitra, analyticko-legislativního odboru Policejního prezídia a Ředitelství služby pořádkové policie Policejního prezídia k některým otázkám týkajícím se aplikace právnî úpravy donucovacích prostředků ze dne 10. 10. 2010.

76 Srov. \29 odst. 2 trestního zákoníku.

77 Srov. \ 38 odst. 1 písm. a) zákona ČNR č. 283/1991 Sb., o Policii České republiky, ve znění pozdějších předpisů, dle něhož mohl policista použít donucovací prostředek údery a kopy pouze v sebeobraně. 
zbraně jako jeden z důvodů nutnou obranu uvádí. ${ }^{78}$ Možnost použití zbraně v nutné obraně podle zákona o policii je však omezena ustanovením \56 odst. 4 zákona o policii, kde se mimo jiné uvádí, že v případě použití zbraně je policista povinen co nejvíce šetřit život osoby, proti níž zákrok směřuje. Podobně jako v př́ípadě donucovacích prostředků se opět jedná o restriktivní ustanovení, které nad míru stanovenou obecným ustanovením o nutné obraně ( $\int 29$ odst. 2 trestního zákoníku) zužuje právo policistů na obranu vlastního života. ${ }^{79}$

Na rozdíl od dřívější právní úpravy zákon v současnosti již nerozděluje prostředky státního donucení svěřené policii na mírnější (donucovací prostředky) a oprávnění k použití zbraně, ${ }^{80}$ ani na běžné a speciální. ${ }^{81} \mathrm{I}$ přesto, že zákon bližší specifikaci ani dělení donucovacích prostředků neuvádí, ${ }^{82}$ vzhledem k povaze jednotlivých donucovacích prostředků a jejich předpokládanému účinku na lidské tělo by bylo možno donucovací prostředky bezpochyby rozdělit na „mírnějšíi“ a „důraznějšíi“ ${ }^{83}$ Zdrojem pro takové rozdělení donucovacích prostředků je především obsah omezujícího ustanovení \58 odst. 1 zákona o policii. Z obsahu tohoto ustanovení lze dovodit, že za mírnější donucovací prostředky lze považovat hmaty, chvaty, pouta a prostředek k zamezení prostorové orientace. Stejné rozdělení donucovacích prostředků na mírnější a důraznější lze dovodit i z judikatury. ${ }^{84}$

Logickou součást zásady přiměřenosti představuje zásada subsidiarity. V souvislosti s použitím donucovacích prostředků se jedná o vztah mezi mírnějšími a dưraznějšími donucovacími prostředky. ${ }^{85}$ Nicméně zákon, interní normativní instrukce ani judikatura neupravují obecnou zásadu subsidiarity ve vztahu k použití donucovacích prostředků,

78 Srov. $\int 56$ odst. 1 písm. a) zákona o policii.

79 Právo na obranu vlastního života lze považovat za jedno z nejzákladnějších mezinárodně a ústavně zaručených práv vůbec. Viz čl. 2 odst. 2 písm. a) Sdělení federálního ministerstva zahraničních věcí č. 209/1992 Sb., o sjednání Úmluvy o ochraně lidských práv a základních svobod a Protokolů na tuto Úmluvu navazujících, ve znění pozdějších předpisů (dále jen „Úmluva“) a čl. 6 odst. 1 věta první a odst. 4 Listiny.

80 Srov. \32 až 36 zákona č. 40/1974 Sb., o Sboru národní bezpečnosti, ve znění pozdějších předpisů.

81 Srov. S 39a odst. 2 zákona ČNR č. 283/1991 Sb., o Policii České republiky, ve znění pozdějších předpisů.

82 „Zákon o policii donucovaci prostredek nedefinuje pojmově, ale pomoci enumerace prostredkù, které zabrnuje do množiny

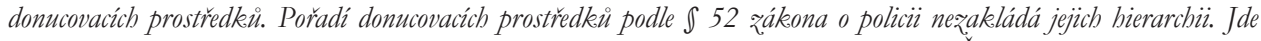
o poubý výcet možných prostredku vyư̌itelných prì zákroku k ochraně chránèných zájmưc. ŠKODA, J., F. VAVERA a R. ŠMERDA. Zákon o policii s komentárem. 2. vyd. Plzeň: Aleš Čeněk, 2009, s. 199 a 208.

83 Mimo to lze donucovací prostředky rozdělit též z hlediska objektu jejich použití, a to na:

a) donucovací prostředky, určené pro použití vưči jednotlivým osobám (např. hmaty, chvaty, údery a kopy),

b) donucovací prostředky, které jsou účinně použitelné především proti skupinám osob (např. vodní stř́kač) a

c) donucovací prostředky, které jsou účinně použitelné proti vozidlu (např. zastavovací pás).

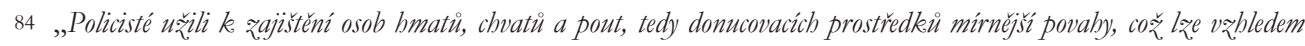
$k$ dané situaci hodnotit jako postup plně odpovidajici požadavku primérenosti“. Rozsudek Nejvyššího správního soudu ze dne 22. 2. 2017, č. j. 2 As 216/2016-92.

85 Srov. Rozsudek Nejvyššího soudu ČR ze dne 5. 10. 2016, sp. zn. 30 Cdo 5661/2015. 
tedy povinnost zasahujícího policisty vyčerpat při zásahu nejprve veškeré mírnější donucovací prostředky. ${ }^{86,87}$ Zákon v souvislosti s volbou míry intenzity zásahu do práv a svobod osob v př́padě použití donucovacích prostředků stanoví pouze výše zmíněné obecné kritérium nastavující mantinely pro naplnění zásady proporcionality ${ }^{88}$ vyjádřené v \53 odst. 3 písm. a) a b) a odst. 5 zákona o policii. Z právně-teoretického hlediska může mít protiprávní jednání na základě určení míry jeho nebezpečnosti a intenzity tři základní formy, kterými je útok, aktivní odpor ${ }^{89}$ a pasivní odpor. ${ }^{90}$ Vodítkem pro výběr vhodného donucovacího prostředku (tedy mírnějšího či důraznějšího), může být podřazení protiprávního jednání pod jednu ze tř̌i výše zmíněných forem protiprávního jednání.

\section{Vybrané príípady z praxe}

Oprávnění k použití donucovacích prostředků je s ohledem na proměnlivost a nepředvídatelnost situací, ve kterých se policisté při plnění svých úkolů mohou ocitnout, formulováno prostřednictvím obecného zákonného zmocnění. ${ }^{91}, 92$ Negativním projevem tohoto legislativně technického řešení je však častý výskyt neurčitých právních pojmů v těchto typech ustanovení. ${ }^{93} \mathrm{Z}$ tohoto důvodu jsou policisté na místě zásahu nuceni vždy nejprve vyhodnotit situaci a prostřednictvím aplikace správního uvážení spojeného

86 Jedinou výjimku tvoří elektrický donucovací prostředek, který je policista oprávněn použít pouze v případě, kdy by použití jiného (mírnějšího) donucovacího prostředku zjevně nebylo dostatečné k dosažení účelu sledovaného zákrokem. Srov. \53 odst. 4 zákona o policii. V tomto případě se však jedná o zvláštní vyjádření zásady subsidiarity, vztahující se pouze k tomuto jedinému donucovacímu prostředku.

87 Srov. Rozsudek Nejvyššího soudu ČR ze dne 5. 10. 2016, sp. zn. 30 Cdo 5661/2015.

88 Mimo výše zmiňované zvláštní omezení vyjádřeného v \58 odst. 1 zákona o policii.

89 „Aktivním odporem lze rozumèt násilné bránèni realizaci služebníbo zákroku“. ŠKODA, J., F. VAVERA a R. ŠMERDA. Zákon o policii s komentárem. 2. vyd. Plzeň: Aleš Čeněk, 2013, s. 201.

90 Srov. Ibid., s. 201.

91 Dle $\int 53$ odst. 1 zákona o policii ,Je policista oprávněn použít donucovací prostředek k ocbraně bezpečnosti své osoby, jiné osoby nebo majetku anebo ko ochranè verejného porádku".

92 Obecné zákonné zmocnění je legislativně technicky tvořeno tak, že se do hypotézy právní normy vsunují výrazy (neurčité právní pojmy) jako např. „,veřejný pořádek“, „bezpečnost“, atd. Tyto výrazy vyjadřují ve zkratce stav, který existuje, jestliže jsou v podstatě dodržena pravidla chování lidí, která sice nejsou výslovně a podrobně vyjádřena v právní normě, jsou však právně závazná, nebot' je nutné je dodržovat podle obecného přesvědčení lidí v určitém čase a v určitém místě. Srov. LUKEŠ, Z. Základy beapečnostního práva. Praha: ACADEMIA, 1971, s. 78.

93 „Tendenci zákonodárce je upravit činnost verejných sborů co možná nejprěsnèji, cožje konformni s požadavkem právní jistoty jako:žto atributu právního státu. Trvale se však pri tom setkává s tim, že ze samotné podstaty postaveni a posláni verejných sboru plyne mnohostrannost jejich úkolu a nepredvídatelnost situací, do nichž se mohou jejich príslušnici dostat a keteré budou muset řešit. Zákonodárce to nékede réš́ żminènými obecnými autorizačními doložkami, avšak i tam, kede jsou formulována żmocnèni více méné konkrétní, děje se tak často za pouřití neurčitých právních pojmü, k. nimž patrú právě výrazy bezpečnost, porádek a veřejný porádek“. MATES, P., J. ŠKODA a F. VAVERA. Veřejné sbory. 1. vyd. Praha: Wolters Kluwer ČR, 2011, s. 11. 
s výkladem neurčitých právních pojmů rozhodnout o tom, zda se jedná o stav, při jehož nastoupení jsou podle zákona oprávněni a zároveň povinni provést úkon či zákrok. ${ }^{94}$

Využívání výše zmíněné legislativní techniky v případě pozitivního vyjádření oprávnění policie má nevyhnutelně za následek konsekvence do oblasti kontroly zákonnosti. Nebot' na rozdíl od přezkumu správních rozhodnutí vzešlých z formalizovaného procesu uskutečňovaného v podobě správního řízení, klade následný přezkum zákonnosti postupu policie na kontrolní orgány daleko větší nároky. Odpověd’ na otázku zda se v daném př́ipadě jednalo o nezákonný zásah či zda naopak neuskutečněním zásahu došlo k nezákonné nečinnosti, nemusí být v řadě případů zcela jednoznačná.

Pro bezprostřední zásahy je typické, že se zpravidla odehrávají ve složitých emočně velice vypjatých situacích, které mohou být zároveň i značně nepřehledné. ${ }^{95}$ Míra přesnosti s jakou jsou zasahující policisté v rámci správního uvážení schopni vyhodnotit situaci na místě zákroku tak často odpovídá dostupným, mnohdy pouze dílčím informacím či nejednoznačně se jevícím skutečnostem. Rozhodnutí provést zákrok tak může být podloženo třeba jen důvodnou obavou, ${ }^{96}$ že je bezprostředně ohrožen významný zákonem chráněný zájem. ${ }^{97}$ Nicméně i v tomto př́ípadě je vždy třeba důsledně dbát na naplnění vzájemné proporcionality mezi zásadou iniciativy a zásadou zdrženlivosti. Z judikatury lze dovodit tři rozhodující kritéria určující míru zavinění konkrétních policistů v př́ípadě porušení zásady zdrženlivosti, jež mělo za následek nezákonnost zásahu, či o zákonnosti zásahu zavdávalo pochybnost.

a) První kritérium představuje zodpovězení otázky, zda dotyční policisté jednali v „dobré či zlé víře“, tedy zda měli za to, že svým jednáním plní úkoly policie a naplňují zásadu iniciativy (přičemž však z objektivního hlediska jednali v pozitivním právním omylu), ${ }^{98}$ či zda si byli od počátku vědomi nezákonnosti svého jednání.

94 Správní uvážení se vyskytuje ve dvou formách, kterými jsou „uvážení jednáni““ a „uvážení volby“. V případě uvážení jednání př́slušná úřední osoba rozhoduje o tom, zda v dané situaci uplatní zákonem předvídaný postup. Uvážení jednání je zpravidla spojeno s výkladem neurčitých právních pojmů. V př́ípadě uvážení volby správní orgán rozhoduje o uplatnění jednoho z více možných právních nástrojů určených pro řešení předmětného případu. Srov. SKULOVÁ, S. Spránni wáǎžení. Základni charakteristika a souvislosti pojmu. 1 vyd. Brno: MU, 2004, s. 28.

95 Policisté jsou mnohdy ve zlomku vteřiny žalobci, soudci i vykonavateli rozhodnutí. Srov. MATES, P. Správni uvážení. 1. vyd. Plzeň: Aleš Čeněk, 2013, s. 96.

96 V tomto př́padě se jedná o neurčitý právní pojem, který je třeba ve vztahu ke konkrétní situaci správně vyložit.

97 Např́klad v př́padě kdy dojde k namíření reálně vypadající makety či skutečné, ale nenabité střelné zbraně držené v rukou pachatele loupežného přepadení na zasahujícího policistu, je policista dle $\int 56$ odst. 1 písm. a) zákona o policii oprávněn proti této osobě použít zbraň, a to bez toho, že by měl povinnost nejprve zjišt'ovat skutečný stav věci, o němž nejsou důvodné pochybnosti, tedy v tomto prípadě to, zda se jedná o skutečnou střelnou zbraň či zda je tato zbraň nabitá.

98 Jako prŕklad lze uvést předvedení osoby policií na žádost obvodní lékařky na specializované pracoviště k psychiatrickému vyšetření $\mathrm{z}$ důvodu podezření na duševní poruchu, která se však u dotyčné osoby později v rámci provedeného vyšetření neprokázala. „Z vy̌še uvedeného je zréejmé, že asistence Policie ČR byla bezprostredním donucovacím

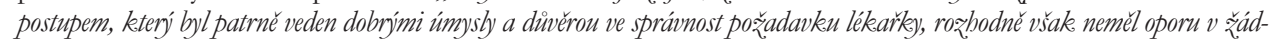
ném z. uvedených zákonu a ve syých düsledcich omezil, byt' na kratši dobu, osobni svobodu stěžovatelky zaručenou čl. 8 odst. 1 a 6 Listiny základních práv a svobod". Nález Ústavního soudu ze dne 18. 5. 2001, sp. zn. IV. ÚS 639/2000. 
b) Dalším neméně významným kritériem je závažnost následku, který v souvislosti s nezákonným zásahem vznikl. ${ }^{99}$

c) Za třetí je třeba vzít v potaz subjektivní vnímání dané situace z pohledu zasahujících policistů, vytvořené na základě v tu chvíli dostupných informací a jejich logického vyhodnocení, jež může mít v krajním př́padě za následek jednání v pozitivním skutkovém omylu.

Nejvyšší správní soud v této souvislosti vyslovil názor, že provedení zásahu na základě chybného vyhodnocení situace, za podmínky, že policisty zvolené řešení odpovídalo dostupným informacím a že zasahující policisté jednali v „dobré víře“ nemusí nutně automaticky zakládat jeho nezákonnost. ${ }^{100}$ Nebot’ pokud bychom připustili, že i špatný taktický postup zasahujících policistů automaticky zakládá nezákonnost daného zákroku, nepochybně bychom tím výrazně oslabili pozici veřejné moci v situacích, kdy prostřednictvím realizace bezprostředních zásahů dochází k odvracení závažného nebezpečí při ochraně významných zákonem chráněných celospolečenských zájmů. ${ }^{101}$

Při bližším pohledu na judikaturu, jejímž předmětem je posuzování přiměřenosti zásahů uskutečněných ze strany policie, lze vysledovat jisté rozdíly v př́stupu na jedné straně Nejvyššího správního soudu a na druhé straně Ústavního soudu. Jako př́klad lze uvést odlišný pohled na otázku určení nositele důkazního břemene $\mathrm{v}$ případě podezření na špatné zacházení, ke kterému mohlo dojít v době zásahu nebo následně v době omezení osobní svobody ze strany policie.

V obecné rovině lze konstatovat, že ve věcech výkladu zásady proporcionality v souvislosti s užitím sily ze strany policie se judikatura Ústavního soudu názorově blíží stanoviskům zastávaným Evropským soudem pro lidská práva (dále jen „ESLP“), jež dlouhodobě zaujímá značně odmítavý postoj k toleranci jakékoliv disproporcionality v jednání, učiněném ze strany orgánů veřejné moci, jež má povahu zásahu do práv a svobod osob omezených na svobodě.

99 „At' již byla divodem pro jeho roz̧odnuti k zákroku viči poškozenému služebni horlivost, nebo otázka osobni prestiže, je mimo jakoukoliv pochybnost, že šlo spiše o impulzivni roz̧odnutí, než o rádné z̧hodnoceni dané situace a posouz̧ení

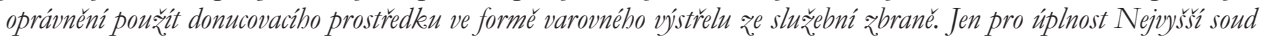
dodává, že soudy nižšich stupño se spoleblivè a prèsvédǔivè vyporádaly jak s otázkou zavinèni obvinènébo na zprisobeném

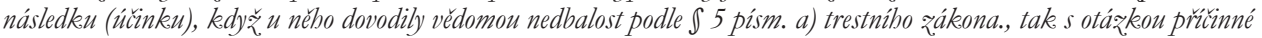
souvislosti mezi takovou formou zavinèni a téžsim následkem, a odvolaci soud priléhavé reagoval i na odvolaci námitku obvinèného vątabujici se k problematice tzv. negativního skutkového omylu. Jestliže nakonec uzavřely, že obvinèný svým jed-

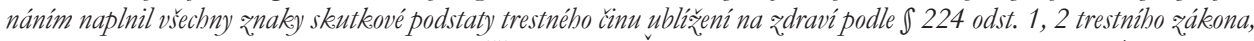
nelze jim ničeho vytknout". Usnesení Nejvyššího soudu ČR ze dne 2. 6. 2010, sp. zn. 8 Tdo 353/2010.

100 „Ani chybnè vyhodnocená situace nemusi vést væ̌dy ke označeni policejního postupu za nezákonný, jestliže zuolené rè̌eni odpovidalo (nutně neúplným) informacím známým zasabujuímu policistovi v dobé zásahu, a tomu, jak se situace musela jevit rozumně wvažujícímu a náležitě vycvičenému policistovi jednajicimu v dobré víré.". Rozsudek Nejvyššího správního soudu ze dne 25. 5. 2015, č. j. 6As 255/2014-42.

101 „Policie si musi zachovat vysokou míru akceschopnosti prì ochraně práv osob a veřejnébo porádku. Nelze proto klást na policejni roẓhodováni v terénu nadmérné a nerealistické požadavky, nebot' to by moblo mít do budoucna rdousici dopad na policejni iniciativu. Určitou míru disproporce zásabu lže akceptovat a pričíst ji na vrub omezené době pro rozhodování ve vypjaté situaci“. Rozsudek Nejvyššího správního soudu ze dne 25. 5. 2015, č. j. 6As 255/2014-42. 
Princip obráceného důkazního břemene, který má svůj původ v judikatuře ESLP přijaly a ve své rozhodovací praxi též uplatňují i české národní soudy. Princip obráceného důkazního břemene spočívá $\mathrm{v}$ tom, že v př́padě kdy osoba omezená na svobodě ze strany orgánů veřejné moci tvrdí, že se stala obětí špatného zacházení, musí stát přesvědčivě prokázat, že k jednání, jež má povahu špatného zacházení, po dobu omezení osobní svobody nedošlo. Při posuzování zavinění se vychází z předpokladu, že pokud se dotyčná osoba před omezením osobní svobody těšila dobrému zdraví a po propuštění na svobodu trpí zraněním, vyvstává zde vyvratitelná domněnka, že ke zranění došlo v době omezení osobní svobody. Princip obráceného důkazního břemene se uplatňuje i na dobu okamžiku zadržení, zajištění či zatčení. ${ }^{102}$

V praxi ovšem zpravidla vyvstává problém s prokázáním „dobrého zdravi“", tedy absenci zranění v době před zásahem. Nebot’ osoba, proti níž byl zásah uskutečněn, může mít na těle zranění, vzniklá před tím než přišla do kontaktu s policisty, přičemž př́íinou těchto zranění může být například právě její protiprávní jednání, jež bylo důvodem $\mathrm{k}$ zásahu policie. ${ }^{103}$ Rozlišit v rámci následného dokazování ta zranění, která mají svưj původ v předchozím jednání osoby od zranění vzniklých v souvislosti se zásahem policie je do jisté míry možno na základě posouzení charakteru těchto zranění a předpokládaného mechanismu jejich vzniku lékařem, nicméně ne vždy je posuzující lékař schopen v tomto směru učinit jednoznačný závěr. Nejvyšší správní soud, aniž by v obecné rovině zpochybňoval princip obráceného dưkazního břemene, se v rámci své judikatury vyjádřil v tom smyslu, že jestliže se nepodaří věrohodně prokázat prrímá spojitost mezi zraněním osob a zásahem orgánu veřejné moci, $\mathrm{k}$ přechodu důkazního břemene na stát nedochází. ${ }^{104}$

Naopak Ústavní soud v tomto směru zaujímá stanovisko, že jestliže lékařská zpráva jednoznačně nevylučuje možnost vzniku zranění udávaného stěžovatelem jako důsledek špatného zacházení, jedná se ze strany stěžovatele o hájitelné tvrzení, jež zakládá podmínku pro uplatnění principu obráceného důkazního břemene. $\mathrm{K}$ tomu ovšem Ústavní soud jedním dechem dodává, že není v jeho kompetenci přezkoumávat hodnocení, tedy mimo jiné i přikládání váhy jednotlivým důkazům (např. závěrům přijatým v rámci lékařských zpráv stěžovatelů) jinými soudy. ${ }^{105}$

Osobně se v souladu s názorem Nejvyššího správního soudu domnívám, že uplatnění principu obráceného důkazního břemene má své limity a tento princip není možno bez ohledu na další okolnosti př́ipadu automaticky uplatnit ve všech př́ípadech, kdy osoba propuštěná na svobodu z moci policie trpí zraněním a zároveň tvrdí, že se stala obětí

102 Srov. Nález Ústavního soudu ze dne 17. 10. 2017, sp. zn. II. ÚS 1398/17.

103 Např. pořezané a pohmožděné ruce v případě poškozování cizí věci či podlitiny a pohmožděniny v obličeji vzniklé při rvačce atd.

104 Srov. Rozsudek Nejvyššího správního soudu ze dne 1. 3. 2017, č. j. 6 As 256/2016-79.

105 Srov. Nález Ústavního soudu ze dne 17. 10. 2017, sp. zn. II. ÚS 1398/17. 
špatného zacházení ze strany policie. Nicméně na druhou stranu je třeba říci, že v př́ipadě, kdy lékařská zpráva nestanoví prŕíčinu zranění jednoznačně, je vhodné z důvodu přesvědčivosti argumentace pro neuplatnění principu obráceného důkazního břemene, pokud je to možné, podpořit závěry přijaté v lékařské zprávě dalšími důkazy (např. výpověd'mi nezávislých svědků).

Obecně lze uzavřít s tím, že z důvodu časté absence svědků při zásahu a nejednoznačnosti závěrů vyslovených posuzujícím lékařem je vhodné veškeré činnosti, jež majî podobu bezprostředních zásahů dokumentovat pomocí technického zařízení zaznamenávající obraz i zvuk. Tím se policie vyhne situacím, kdy z důvodu nedostatku jiných důkazů bude princip obráceného důkazního břemene aplikován orgány vykonávajícími soudní kontrolu i v př́padech, ve kterých nemá opodstatnění.

ESLP jde v tomto směru ještě dál, když si v podstatě vytvořil svưj vlastní systém přikládání váhy jednotlivým důkazům předkládaným stranami. V rámci své judikatury ESLP uvádí, že při hodnocení důkazů v případě podezření na špatné zacházení akceptuje důkazní standart, „mimo rozumnou pochybnost“. Takový důkaz může vyplývat z koexistence dostatečně silných, jasných a souhlasných důsledků nebo z nevyvratitelných faktických domněnek. ${ }^{106}$ Nicméně z judikatury ESLP je patrné, že v př́padě podezření na špatné zacházení ze strany orgánů veřejné moci přihlíží k důkazům předkládaným stěžovateli zcela jinou optikou než k důkazům předkládaným odpůrci těchto tvrzení. ${ }^{107}$ Obrana proti př́ipadnému nepravdivému obvinění ze špatného zacházení je tak v řízení před ESLP nejen kvưli uplatnění principu obráceného důkazního břemene, ale též vzhledem $\mathrm{k}$ rozdílnému prrístupu $\mathrm{k}$ hodnotě důkazů předkládaných jednotlivými stranami, jakož i preferenci subjektivního hlediska stěžovatele oproti hledisku většiny zúčastněných osob ${ }^{108}$ věcí značně složitou. ${ }^{109}$

106 Srov. Rozsudek Evropského soudu pro lidská práva ze dne 1. 6. 2010, Gäfgen proti Némecku, sp. zn. 22978/05.

107 Např́klad v kauze Bouyid proti Belgii ESLP odmítl námitky vlády, že lékařská potvrzení předložená stěžovatelem neprokázala, že by zmíněné zranění bylo následkem jednání policistů, ani že toto zranění bylo způsobeno policisty. Mimo to nepřipustil ani možnost (opět tvrzenou vládou), že by si stěžovatel způsobil své zranění sám, aby mohl ze msty za své dočasné omezení svobody vznést obvinění proti policii. Srov. Rozsudek Evropského soudu pro lidská práva ze dne 28. 9. 2015, Bouyid proti Belgii, sp. zn. 23380/09. Na druhé straně v př́padě Eremiásová a Pechová proti České republice ESLP nebyl přesvědčen o důvěryhodnosti tvrzení (podloženého lékařskou zprávou), že poranění eskortujícího policisty pocházelo z útoku dlaní učiněného osobou omezenou policií na svobodě. Srov. Rozsudek Evropského soudu pro lidská práva ze dne 16. 2. 2012, Eremiášváa a Pechová proti České republice, sp. zn. 23944/04.

108 ,Je nutné zdoiraznit, že mirže stačit, pokud je obèt ponižena ze svého vlastníbo pobledu, i kedyž tomu tak není zpobledu jimýcb“. Rozsudek Evropského soudu pro lidská práva ze dne 28. 9. 2015, Bouyid proti Belgii, sp. zn. 23380/09.

109 „....Mř̌reme sice uvažovat nad otázkou, zda si strasburšti soudci trochu neprïbrousili brany néketerých dílu této skládačky,

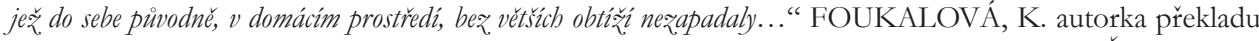
Rozsudku Evropského soudu pro lidská práva ze dne 16. 2. 2012, Eremiásová a Pechová proti České republice, sp. zn. 23944/04. 
Právní vady, které se mohou v průběhu realizace bezprostředních zásahů vyskytnout, lze pro lepší zpřehlednění, s ohledem na příčinu nezákonnosti, rozdělit do čtyř skupin. Obecně lze konstatovat, že nezákonnost zásahu může spočívat:

a) v absolutní věcné nepř́slušnosti osoby, která zásah provádí,

b) v nezákonnosti prostředků zvolených k realizaci zásahu,

c) v neexistenci relevantního právního důvodu k uskutečnění zásahu,

d) v nepřiměřené intenzitě zásahu, ve vztahu k povaze a nebezpečí protiprávního jednání, které bylo zásahem eliminováno.

Na základě výše uvedeného vymezení možných právních vad, jež se mohou v průběhu aplikační činnosti orgánů veřejné moci oprávněných k realizaci bezprostředních zásahů vyskytnout, je možno, a to s ohledem na stupeň závažnosti a povahu těchto vad vedoucích k nezákonnosti postupu, bezprostřední zásahy (podobně jako individuální správní akty) rozdělit na napadnutelné a nicotné. ${ }^{110,111}$

$\mathrm{V}$ tomto ohledu je třeba rozlišit mezi dvěma různými skupinami př́padů, které se stávají předmětem soudní kontroly, přičemž ze strany stěžovatelů u Ústavního soudu a ESLP, stejně jako ze strany těchto soudů, jsou zpravidla vnímány takřka bez rozdílu. ${ }^{112}$

V prvním př́padě se jedná o zásahy policie, pro jejichž uskutečnění v danou chvíli existoval právní důvod, nicméně při jejich realizaci došlo ze strany zasahujících policistů k excesu, který má za následek to, že zásah trpí právní vadou, která ovšem nedosahuje takové intenzity, aby sama o sobě zakládala nicotnost předmětného zásahu. Pokud jde o povahu výše zmíněných méně závažných právních vad, vyskytujících se v souvislosti s použitím donucovacích prostředků ze strany policie, jedná se v praxi nejčastěji právě o porušení zásady přiměřenosti, které může mít podobu:

a) zvolení ve vztahu ke konkrétním okolnostem př́padu nepřiměřeně dưrazného (avšak zákonem upraveného) donucovacího prostředku, ${ }^{113}$

110 „Tato u nás málo prozkoumaná problematika má svou obdobu v teorii správního roz̧hodnutí (rozlišení mez̧i roz̧hodnutimi sice vadnými, pro něž však plati presumpce právnosti, dokud nejsou žrušna, a roz̧odnutími nicotnými, na něz se pro závažnost jejich vad hledí, jako kdyby vỉbec nebyla uăinèna)“. HENDRYCH, D. a kol. Správní právo. Obecná část. 9. vyd. Praha: C. H. Beck, 2016, s. 487.

111 Srov. VŠETIČKA, P. Uplatnění nutné obrany v souvislosti s realizací bezprostředních zásahů. Časopis pro právni védu a praxi [online]. 2018, roč. 26, č. 1, s. 135-148. [cit. 12. 06. 2018]. ISSN 1805-2789. DOI: 10.5817/CPVP2018-1-9. Dostupné z: https://journals.muni.cz/cpvp/article/view/8416

112 Srov. např. př́pad Gäfgen proti Némecku, jehož podstatou bylo zcela nezákonné použití fyzické síly ze strany policie proti osobě nacházející se v její moci a případ Tali proti Estonsku, kde dle rozsudku ESLP došlo při použití donucovacích prostředkư k porušení zásady přiměřenosti, nicméně zde na rozdíl od předchozího př́padu byly použity zákonem předvídané prostředky státního donucení, a to na základě relevantního právního důvodu.

113 Mưže se jednat např́klad o použití slzotvorného donucovacího prostředku v prostorách policejních cel. Nebot' ESLP v této souvislosti zaujal stanovisko, že s ohledem na potenciální zdravotní rizika by podle názoru CPT (Evropského výboru pro zabránění mučení a nelidskému či ponižujícímu zacházení nebo trestánî) neměl být peprový sprej používán v uzavřených prostorách. Soud dále konstatoval, že v prostorách policejních cel se jedná o neprriměřný donucovací prostředek a jeho použití v těchto místech vyhodnotil jako nelidské a ponižující zacházení. Srov. Rozsudek Evropského soudu pro lidská práva ze dne 13. 2. 2014, Tali proti Estonsku, sp. zn. 66393/10. 
b) zvolení ve vztahu ke konkrétním okolnostem případu adekvátního donucovacího prostředku, ovšem použitého s intenzitou žrejmě nepřiměřenou povaze a nebezpečnosti protiprávního jednání, které bylo zásahem eliminováno. ${ }^{114}$

Oproti tomu je třeba odlišit zcela nezákonné použití síly či hrozby jejîho použití ze strany příslušníků policie, pro něž neexistuje žádné zákonné zmocnění. V tomto prípadě se jedná o použití donucovacích prostředků, častěji však jiných forem fyzického či psychického násili či hrozby jeho použití neupravených v zákoně, zcela bez právního důvodu. ${ }^{115}$ Zde je ovšem třeba ř́ci, že takový postup policie je postižen tak zásadními právními vadami, které je zbavují povahy projevů veřejné správy a činí jej zcela nicotným. To má mimo jiné za následek tu skutečnost, že otázka přiměřenosti již není $v$ tomto př́padě jakkoliv relevantním faktorem, nebot' je vedle ostatních právních vad bezvýznamná. Zpravidla se jedná o př́pady, kdy je prostřednictvím nezákonného postupu policie, který naplňuje skutkovou podstatu úmyslného trestného činu přímo ohrožen život či zdraví osoby. ${ }^{116} \mathrm{Z}$ judikatury ESLP vyplývá, že nezákonné použití síly či hrozby jejîho použití ze strany policie bývá nejčastěji uplatněno bud' za účelem msty za nevhodné chování osoby, která je v moci policie ${ }^{117}$ nebo v rámci trestního ve snaze získání informací či doznání podezřelé osoby. ${ }^{118,119}$

114 Napřx. př́liš silné nasazení (utaženî) pout, jež byla osobě omezené policií na svobodě přiložena ze zákonného důvodu. Viz „Nasazeni pout obvykle neni z. blediska cll. 3 Úmluvy problematické, pokud bylo toto opatrení použito v souvislosti se zákonným zať̌ením nebo zadržením. V žádném př́padě však pouta nemohou být nasazena prúliš

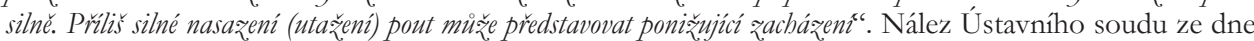
24. 5. 2016, sp. zn. I. ÚS 1042/15.

115 „Zákeon ani jiná právni norma (napr. pokyn policejního prezidenta) policistiom neumožñuji, aby ke plnèni kterébokoliv

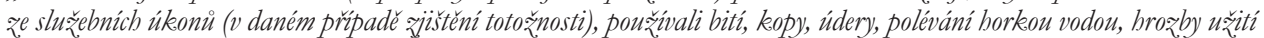
zbranè. Užili-li obvinèni takových prostredkèi, pak jednali zcela mimo oprávnèní, kterými je zákon vybavil pro plnèní jejich úkoliu. Takový postup neni zákonným a nestává se ospravedlnitelným, ani pokud se osoba podęrelá ze spáchání trestnébo činu bráni zjištèni své totožnosti ly̌i. Policisté jsou oprávnèni k. plnèni svých úkolü použit toliko zákonem dovolených

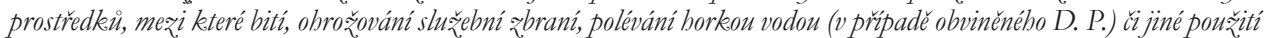

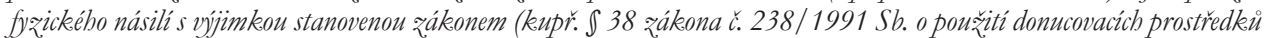
policistou) jednoznačně nepatrü. "Usnesení Nejvyššího soudu ze dne 24. 6. 2009 sp. zn. 8 Tdo 677/2009.

116 „Poškozený H. S. L. v dìsledku společného jednáni obžalovaných pprap. Bc. J. S. a K. S. utrpèl té̌žké zranéní, a to zlomeniny 9. a 10. žebra vlevo a protrženi sleziny s následným kervácenim do dutiny bríšni; vąhledem k. tomu, že mu nebyla v̌́as poskytnuta kevalifikovaná lékeaŕská pomoc, pak dne 5. 1. 2009 v 02.45 hod. na následky zranéní zemřel, kedyž. v opačném př́padě, pokud by obžalovaní, jako členové hlídky Policie ČR, včas privolali lékeařskou pomoc nebo událost oblásili svému nadriżenému a poškozenému byla věas privolána lékařská pomoc bylo by možno jej s vysokou pravdèpodobností uchovat pri životé. Usnesení Nejvyššího soudu ze dne 29. 3. 2012, sp. zn. 6 Tdo 213/2012.

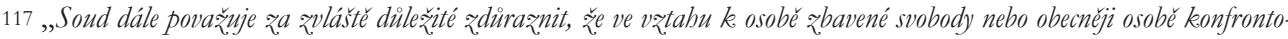
vané s príslušniky donucovacich orgánui, jakékooliv pouǧiti fyzické sily, které nebylo nezbytně nutné s obledem na jeji vlastní chováni, snižuje lidskou düstojnost a je v zásadě porušenim práva zakotveného v čl. 3 Úmluvy. Použití fyzické sily jako reakece na postoj vnimaný jako neuctivý nebo urážlivý neodpovídá požadavku nezbytnosti “. Rozsudek Evropského soudu pro lidská práva ze dne 28. 9. 2015, Bouyid proti Belgii, sp. zn. 23380/09.

118 Zde je možno zmínit např́klad př́pad Magnuse Gäfgena, který se stal obětí nezákonného policejního násilí (jednalo se např. o hrozbu velkou bolestí, či sexuálním zneužitím ze strany spoluvězňů organizovaného policiî) uplatněného za účelem odhalení místa, kde se nachází tělo jeho oběti. Viz Usnesení třetí komory druhého senátu Spolkového ústavního soudu ze dne 14. prosince 20042 BvR 1249/04 marg. (1-14). Dostupné z: https://www.bundesverfassungsgericht.de/SharedDocs/Entscheidungen/DE/2004/12/ rk20041214_2bvr124904.html;jsessionid=D9A9AAA7F2E31B6742CFCF2E0E7E286C.2_cid370 
V př́padě, kdy v souvislosti s použitím donucovacích prostředků dojde $\mathrm{k}$ prokazatelnému porušení zásady přiměřenosti, nelze jistě pochybovat o tom, že zásah není právně bezvadný. Nicméně označení postupu policie pouze z důvodu porušení zásady přiměřenosti spočívající ve volbě vzhledem $\mathrm{k}$ okolnostem případu nepřiměřeně dưrazného donucovacího prostředku či v nepřiměřeně intenzivním použití adekvátního donucovacího prostředku za mučení nebo jiné nelidské či ponižující zacházení dle mého názoru značně převyšuje míru jeho nezákonnosti. ${ }^{120}$

Ústavní soud ve shodě s judikaturou ESLP uplatňuje při hodnocení priměřrenosti zásahů realizovaných ze strany př́íslušníků bezpečnostních sborů zásadu nezbytnosti. ${ }^{121}$ Účelem této zásady je zakotvení striktní proporcionality v př́padě použití síly ze strany orgánů veřejné moci, a to nejen vưči osobám, jejichž svoboda je omezena, ale obecně všem osobám, jež jsou konfrontovány s př́slušníky donucovacích orgánů. ${ }^{122}$

Zásada nezbytnosti, skrze kterou Ústavní soud a ESLP posuzuje přiměřenost postupu policie v př́padě použití donucovacích prostředků, však zcela neodpovídá zásadě přiměřenosti vyjádřené v $\int 53$ odst. 5 zákona o policii, kde se uvádí, že policista při použití donucovacího prostředku dbá na to, aby nezpưsobil osobě újmu zř́jmě neprriměřenou povaze a nebezpečnosti jejîho protiprávního jednání, z čehož vyplývá, že policistům umožňuje způsobení i nepřiměřené újmy ve vztahu k povaze a nebezpečnosti protiprávního jednání. ${ }^{123}$ Zásada nezbytnosti či striktní proporcionality v podobě prezentované

119 ESLP v této souvislosti konstatoval, že motivace k nezákonnému použití síly ze strany policie (např. snaha o záchranu lidského života) jakož i povaha trestného činu ze kterého je dotyčná osoba podezřelá, je irelevantní, nebot' z čl. 3 Úmluvy neexistují žádné výjimky a žádná odchylka od něho není povolena ani v případě veřejného ohrožení státní existence (boj s terorismem a organizovaným zločinem). Viz Rozsudek Evropského soudu pro lidská práva ze dne 1. 6. 2010, Gäfgen proti Německu, sp. zn. 22978/05.

120 Viz prípad Tali proti Estonsku, kde byly ze strany př́islušných úředních osob (vězeňské služby) použity zákonem upravené donucovací prostředky (mimo jiné slzotvorný donucovací prostředek), a to na základě relevantního právního důvodu (protiprávního jednání osoby, proti níž zásah směřoval). Nicméně ESLP vyhodnotil takový postup vězeňské služby jako nelidské a ponižující zacházení a to pouze z důvodu použití (dle názoru ESLP) nepřiměřeně dưrazného donucovacího prostředku (peprového spreje) v prostoru vězeňské cely. Srov. Rozsudek Evropského soudu pro lidská práva ze dne 13. 2. 2014, Tali proti Estonsku, sp. zn. 66393/10.

121 ,Jakékoliv donucovaci prostredky je nutno pouřivat pouze v míre nezbytně nutné pro dosažení legitimního účlu sledovaného zákerokem“. Nález Ústavního soudu ze dne 27. 10. 2015, sp. zn. I. ÚS 860/15.

122 Viz např. Rozsudek Evropského soudu pro lidská práva ze dne 28. 9. 2015, Bouyid proti Belgii, sp. zn. 23380/09 či Nález Ústavního soudu ze dne 17. 10. 2017, sp. zn. II. ÚS 1398/17.

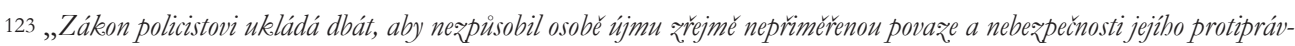
ního jednání. Zákon tedy obdobnè jako u obecnébo institutu nutné obrany nenařzuje prìsnou proporcionalitu. Umožñuje zpuisobit osobě donucovacím prostredkem újmu neprimèrenou, hranici stavi o nèco výse až na úroveñ žrejmé, tedy zjevné,

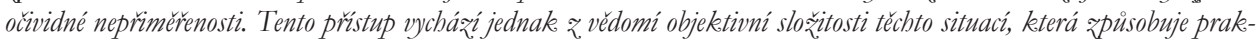
tickou nenaplnitelnost požadavku prìsné proporcionality, a jednak zpovaby efektivního zákroku (obrany), kedy empirická zkušenost dokládá, že aby byl zákrok (obrana) účinný, je zpovaby véci nezbytné, aby byl o něco razantnèjsí, nežje útok. č jiné nebezpečné jednání, proti némužje zakeročováno". Rozsudek Nejvyššího soudu ČR ze dne 5. 10. 2016, sp. zn. 30 Cdo 5661/2015. 
Ústavním soudem a ESLP není v zákoně o policii ani v žádném jiném právním předpise pozitivně vyjádřena, nicméně vzhledem k významu judikatury Ústavního soudu a ESLP je možno hovořit o praktickém zúžení rozsahu zásady přiměřenosti vyjádřené v \53 odst. 5 zákona o policii.

Zúžení rozsahu zásady přiměřenosti vyjádřené v \53 odst. 5 zákona o policii není ovšem jediným omezením pozitivní právní úpravy v souvislosti se zohledněním judikatury ESLP v rámci aplikační praxe. Mimo to je možno zmínit např́iklad omezení možnosti využití ustanovení \25 zákona o policii, které opravňuje policistu k připoutání osoby, která se dopouští protiprávního jednání k vhodnému předmětu. Přestože současná právní úprava (na rozdíl od předchozî) ${ }^{124}$ tento postup nevylučuje ani v prostorách policejních cel, na základě závěrů přijatých v rámci judikatury ESLP $^{125}$ se v praxi toto oprávnění v prostorách policejních cel v současné době již nerealizuje. Podobně je tomu $\mathrm{v}$ případě použití slzotvorného donucovacího prostředku v prostorách policejních cel. ${ }^{126}$ Zásada iniciativy tak jak je upravena v \ 10 odst. 2 zákona o policii obsahuje pouze pozitivní vyjádření př́kazu a podmínek, při jejichž naplnění je policista i v době mimo službu povinen provést úkon (zákrok) nebo přijmout jiné opatření. ${ }^{127,}{ }^{128} \mathrm{Ob}$ sah tohoto ustanovení lze tedy vykládat dvojím různým zpơsobem. A to za prvé tak, že v případě nastoupení okolností taxativně uvedených v zákoně je policista povinen provést úkon či učinit jiné opatření, přičemž v ostatních případech zákonem výslovně neupravených je rozhodnutí o provedení či neprovedení úkonu či jiného opatření ponecháno na jeho vlastním uvážení. Za druhé je možno záměr zákonodárce obsažený v tomto ustanovení chápat i tak, že policista musí uplatnit svoji pravomoc pouze v situacích zákonem výslovně předvídaných. Jedná se tedy o typickou mezeru v zákoně, a tudíž samotný jazykový výklad tohoto ustanovení jednoznačnou odpověd’ na tuto otázku neposkytuje. ${ }^{129}$ Za účelem řešení mezer v právu (což je možno

124 Srov. \16 odst. 2 zákona ČNR č. 283/1991 Sb., o Policii České republiky, ve znění pozdějších předpisů. 125 Viz Rozsudek Evropského soudu pro lidská práva ze dne 25. 7. 2013, Kummer proti Céské republice, sp. zn. 32133/11.

126 Viz Rozsudek Evropského soudu pro lidská práva ze dne 13. 2. 2014, Tali proti Estonsku, sp. zn. 66393/10.

127 Policista je povinen i v době mimo službu provést úkon nebo přijmout jiné opatření, je-li bezprostředně ohrožen život, zdraví nebo svoboda osob anebo majetek nebo došlo-li k útoku na tyto hodnoty. Srov. \10 odst. 2 zákona o policii.

128 Povinnosti provést úkon nebo přijmout jiné opatření je policista zproštěn za podmínek uvedených v $\$ 10$ odst. 4 zákona o policii.

129 Problematiku posouzení oprávněnosti zásahu či naopak př́padné nezákonné nečinnosti lze demonstrovat na př́padu policisty $\mathrm{D}$. K., který $\mathrm{v}$ době mimo službu $\mathrm{v}$ areálu nejmenovaného supermarketu rozpoznal muže, o kterém ze své policejní praxe věděl, že je hledanou osobou, a to z důvodu nenastoupení výkonu trestu odnětí svobody. Přestože byl v danou chvíli dotyčný policista v civilu a mimo službu, prokázal se muži služebním průkazem policie a pokusil se jej zadržet a vyčkat s ním na místě do př́ijezdu přivolané hlídky policie. Podežrelý muž však policistu fyzicky napadl a způsobil mu lehčí zranění. Napadený policista se posléze domáhal určení toho, že v daném př́padě postupoval v souladu se zásadou iniciativy a tudíž v okamžiku napadení požíval právní ochrany pramenící z jeho postavení jakožto úřední osoby. 
vztáhnout i na mezery v zákoně) Z. Kühn rozlišuje tři formy legislativního vyjádření zákazu a dovolení, kterými je:

a) Silný zákaz - představuje tu vlastnost normy N, podle níž chování $p$ je za okolností $q$ silně, tedy výslovně zakázáno,

b) Silné dovolení - se rozumí ta vlastnost normy N, podle níž chování $p$ je za okolností $q$ silně, tedy výslovně dovoleno a c) Slabé dovolení - zakládá tu vlastnost normy N, podle níž pro chování $p$ za okolností $q$ nevyplývá ani zákaz ani dovolení. A tudíž z kritéria kvalifikační úplnosti typu „vše je dovoleno, co není zakázáno“ následně vyplývá dovolení chování $p$ za okolností $q .{ }^{130}$

Na základě podřazení obsahu ustanovení \10 odst. 2 zákona o policii pod toto schéma lze vyslovit závěr, že se $\mathrm{v}$ tomto př́padě jedná o vyjádření slabého dovolení a tudíž je policista v souladu s tímto ustanovením i v době mimo službu (za splnění ostatních zákonných podmínek) oprávněn uplatnit svoji pravomoc, jestliže došlo k ohrožení nebo porušení vnitřního pořádku a bezpečnosti, jehož odstranění spadá do úkolů policie, a to i nad rámec forem protiprávního jednání v tomto ustanovení výslovně upravených.

\section{Závěr}

Vyjasnění vzájemného vztahu zásady přiměřenosti, potažmo zásady zdrženlivosti a zásady iniciativy na teoretické úrovni představuje zásadní předpoklad pro efektivní fungování policie v rámci aplikační praxe. Nebot' právě tato dvojice zásad stanovuje mantinely při realizaci zákonem svěřených oprávnění. Mimo klasického střetu dvou právních zásad, se tyto dvě zásady nejen vzájemně vylučují, ale v jistém smyslu též doplňují. Každá z těchto zásad má za cíl zabránit použití krajních prostředků při řešení situace, a to v opačném protipólu míry aktivity. ${ }^{131} \mathrm{Na}$ jedné straně spektra intenzity zásahu stojí nezákonná nečinnost a na druhé překročení zákonem svěřené pravomoci.

Nejvyšší soud však k takovému postupu policisty zaujal jednoznačně negativní stanovisko, a to v tom smyslu, že „...postupem, který zuolil, nevykonával svoji pravomoc, svoji pravomoc prekeročil a tím pádem vỉbec nemobl poživat ochrany úredni osoby“. Usnesení Nejvyššího soudu ČR ze dne 10. 7. 2013, sp. zn. 7 Tdo 653/2013. Nicméně autoři komentáře k zákonu o policii mají na daný případ zcela odlišný názor. „... Na zákeladě výse uvedenébo lzee konstatovat, že prǐslušník policie, keterý byl v době provádèní úkonu mimo službu, nebyl povinen úkon provést. Tedy neprovedeni daného úkonu by nezakládalo odpovédnost za nezákonnou nečinnost. Pokud se však i presto rozhodl vz̧bledem k okolnostem úkon provést, byl ke tomu oprávnèn, nebot'se pobyboval v mezích úkolu (puisobnosti) policie dle \} 2 \text { zákona o policii“. } ŠKODA, J., F. VAVERA a R. ŠMERDA. Zákon o policii s komentárem. Plzeň: Aleš Čeněk, 2009, s. 68.

130 Viz KÜHN, Z. Aplikace práva ve složitých prípadech. K úloẓe právních principuo v judikature. 1 vyd. Praha: Karolinum, 2002, s. 216-217.

$131 \mathrm{~V}$ tomto duchu se vyjádřil i Nejvyšší soud ČR, když ve své judikatuře odkazuje na závěry přijaté v rámci nauky. Viz „Cinnost policejního sboru je obecně ovládána dvojici zásad, jimiž jsou zásada primérénosti a zdrženlivosti a zásada iniciativy. Tyto dvě zásady typicky puisobi každá v opačném smèru a regulují činnost policejního sboru tak, aby na jedné straně nedocházelo ke nečinnosti, a tím absenci ochrany práv osob, ale aby současnè také nedocházelo ke takovému aktivnimu plnèni úkolu policie, keteré by zasabovalo nad míru nezbytnou do práv či svobod osob. Obè zásady je nutno aplikovat vǎdy soǔ́asně (srov. VANGELI, Benedikt. Zákon o Policii Ceské republiky. Komentár. 2. vydání. Praha: C. H. Beck, 2014, s. 64. ISBN 978-80-7400-543-5.)“. Rozsudek Nejvyššího soudu ČR ze dne 5. 10. 2016, sp. zn. 30 Cdo 5661/2015. 
Co se týká hlavních východisek přijatých v rámci předkládaného prríspěvku, je možno vyslovit tři zásadní závěry a několik poznámek. Ve vztahu k ochraně před nezákonnou nečinností policie z provedené analýzy jednotlivých možností vyplývá, že žádný z právních prostředků uplatnitelných obecně v oblasti veřejné správy při ochraně proti nečinnosti v souvislosti s neuskutečněním jiných právních forem realizace veřejné správy neposkytuje okamžitou ochranu proti nezákonné nečinnosti ze strany policie, jež spočívá v neuskutečnění bezprostředního zásahu, na jehož realizaci existuje právní nárok. Těžiště ochrany tak spočívá $\mathrm{v}$ uplatnění nároku na náhradu př́ípadně vzniklé škody či nemateriální újmy.

Poměrně podrobně jsem se zabýval otázkou právní povahy zásahu uskutečněného policistou $\mathrm{v}$ době mimo službu a to nad rámec eliminace forem protiprávního jednání výslovně uvedených v $\int 10$ odst. 2 zákona o policii. V této souvislosti jsem dospěl k závěru, že výše zmíněné ustanovení neobsahuje negativní vymezení zásady iniciativy, v důsledku čehož se v zákoně objevuje mezera, a proto je třeba př̀i výkladu tohoto ustanovení použít systematický nikoliv pouze jazykový výklad. V souladu s naukou zaujímám názor, že i v době mimo službu je policista (za splnění ostatních zákonných podmínek) oprávněn uplatnit svoji pravomoc, jestliže došlo k ohrožení nebo porušení vnitřního pořádku a bezpečnosti, jehož odstranění spadá do úkolů policie, a to i nad rámec forem protiprávního jednání $\mathrm{v}$ tomto ustanovení výslovně upravených. $\mathrm{V}$ opačném případě by takové jednání policisty mělo povahu nezákonného zásahu, což dle mého názoru nebylo záměrem zákonodárce $\mathrm{v}$ prrípadě formulace zásady iniciativy.

$\mathrm{V}$ prrípadě bezprostředního ohrožení vlastního života či zdraví nelze policistům uprrít právo na nutnou obranu, a to za splnění stejných zákonných podmínek jako je tomu v případě civilních osob. Vzhledem k jejich veřejně-právnímu postavení se však i v tomto př́padě dle mého názoru stále jedná o výkon veřejné správy. Nicméně otázka přiměřenosti jejich jednání, učiněném v rámci nutné obrany, by měla být hodnocena nikoli podle omezujících ustanovení zákona o policii, ale podle stejných kritérií jako je tomu v případě civilních osob, jinak by byla jejich pozice v oblasti naplnění ústavně zaručeného práva na ochranu vlastního života oproti civilním osobám značně znevýhodněna.

$\mathrm{V}$ rámci námětů de lege ferenda lze poukázat na vhodnost pozitivního vyjádření výše uvedených závěrů v zákoně. Např́iklad ve vztahu k použití donucovacích prostředků by mohl rozšířený text $\int 53$ odst. 5 zákona o policii znít tak, že policista při použití donucovacích prostředků dbá na to, aby nezpůsobil osobě újmu žrejmě nepřiměřenou povaze a nebezpečnosti jejího protiprávního jednání, to neplatí, jedná-li policista v nutné obraně. Podobně v $\int 56$ odst. 4 zákona o policii by mohlo dojít ke změně v tom smyslu, že povinnost co nejvíce šetřit život osoby, proti níž zákrok směřuje, by se nevztahovala na možnost použití zbraně v nutné obraně, přičemž v tomto př́ipadě by se proporcionalita mezi intenzitou útoku a možného následku řídila obecnými podmínkami stanovenými pro naplnění mezí nutné obrany vyjádřenými v \29 odst. 2 trestního zákoníku. 
Současná doporučení ze strany ESLP adresovaná prostřednictvím prŕíslušné judikatury zasahujícím policistům za účelem nastavení standardu v oblasti přiměřenosti použití donucovacích prostředků prŕliš nekorespondují s požadavky na řešení reálných problémů vyskytujících se v rámci aplikační praxe. ${ }^{132}$ Z obsahu judikatury ESLP jejímž předmětem je otázka posouzení pruměřenosti v souvislosti s použitím donucovacích prostředků ze strany policie, lze jednoznačně vysledovat trend směrující $\mathrm{k}$ prŕísné proporcionalitě, vyjádřené prostřednictvím zásady nezbytnosti. Čas ukáže, zda v návaznosti na nepř́íznivý vývoj v oblasti bezpečnosti nahradí ESLP tuto zásadu zásadou nepř́pustnosti extrémní disproporcionality, jež odpovídá zásadě přiměřenosti, tak jak je tato zásada vyjádřena v \53 odst. 5 zákona o policii. ${ }^{133}$

Závěrem je třeba připomenout, že v případě bezprostředních zásahů vzhledem $\mathrm{k}$ absenci formalizovaného procesu, není zvláště odděleno řízení o vydání správního rozhodnutí od jeho výkonu, takže vydání rozhodnutí a jeho výkon neoddělitelně splývají v jediný úkon. ${ }^{134}$ Přitom celý tento úkon provádí často jediná úřední osoba, proti jejímuž postupu není možno uplatnit žádný opravný prostředek, který by disponoval suspenzívním účinkem. Tato skutečnost do jisté míry relativizuje uplatnění veškerých obecných právních zásad.

132 Např. namísto připoutání osoby k vhodnému předmětu doporučuje ESLP při zákroku proti agresivním osobám umístěným v policejních celách, uplatnit méně invazivní postup spočívající v uplatnění zákonných výzev a použití hmatů a chvatů. „Personál policejnich cel by mèl být vyškolen pro použivání jiných, méně nebezpečných metod pro zuládnutí zadř̌ených osob, které prédstavuji riziko pro sebe samé nebo pro jiné osoby, jako napríklad metody ústních pokynu a ručni kontroly“. Rozsudek Evropského soudu pro lidská práva ze dne 25. 7. 2013, Kummer proti Ceské republice, sp. zn. 32133/11. Na tomto místě je však třeba položit si otázku, zda připoutání osoby k vhodnému předmětu lze jednoznačně hodnotit jako citelnější zásah do fyzické (případně též psychické) integrity osoby, oproti realizaci znehybňujících úchopů ze strany několika policistů. Především zde vyvstává otázka, jak dlouho či zda vůbec dokáže policista (či několik policistů současně) udržet pouze vlastními silami aktivně se bránící agresivní osobu, která se snaží o sebepoškození pod kontrolou, nehledě na skutečnost, že po tom, co policisté sevření hmatů uvolní, agresivní osoba ve svém jednání zpravidla pokračuje, a to mnohdy s ještě větší intenzitou. Lze si tedy právem položit otázku, zda se v tomto případě opravdu jedná (at' již z hlediska zasahujících policistů či dotyčné osoby) o bezpečnější a „šetrnějšíi“ metodu, než jak je tomu v prrípadě připoutání osoby k vhodnému předmětu.

133 „Evropské ústavni soudnictví, jakoži i Evropský soud pro lidská práva a Evropský soudni dviir stoji dnes pred prïjetim rozhodnutí, v nichž se budou muset vyporádat s kolizi verégného dobra - zajišténi vnitŕni bezpečnosti pred terorizmem a základního práva na ochranu soukromi v situaci, kdy začnáme mluvit o kategorii trv. asymetrickéch konflikti, napřklad v otázkách prǐstupu tajných služeb k odposlechu telefonnich hovorü, k osobním údajüm o cestujicich v letecké dopravé, k monitorováni internetové osobni komunikace, či formou e-maili, skeype apod. v otázkách vytváreni databázi osobnich údaju. Budou konfrontováni s výzvou, zdali testovat uvedenou kolizi príkazem ko optimalizaci, a tím detailnè vymezit obsah a formu uplatnèni verejnébo dobra, anebo se omezi it na vyloučeni extrémni disproporcionality, tedy na vyloučeni takovébo obsabu a formy veréjného dobra, jež ve vątabu k zákeladnímu právu má likvidačni dopady. Znamená to, že test vyloučením extrémní disproporcionality by se pak omezil na test vhodností (čili ₹koumáni vazby legislativníbo prostredku a jím sledovanébo účlu), test potrebnosti a test pomérováni by pak ve srovnáni s postupem optimalizaci byl omezen. Hlubši analýza testu vyloučenim extrémni disproporcionality ale ukazuje dva problémy: Tím pronim je uvédomèni si úzké vazby mezi testem potrebnosti (čili posuzování subsidiarity alternativních legislativnich prostredkei) a testem poměrování, jehož obsahem je Dworkinovo limitní chápáni kategorie principù (na roz̧díl od kolize keterých konfliket norem má za dìsledek uplatnèni pravidla vyloučeni trétího). Problémem drubým je pak samotné vymezeni dober a bremen a jejich klasifikace - jinými slovy axiologický problém otevrené textury práva“. HOLLÄNDER, P. Filozofie práva. 2. vyd. Plzeň: Aleš Čeněk, 2012, s. 238-239.

134 Srov. KINDL, M. et al. Základy správního práva. 2. vyd. Plzeň: Aleš Čeněk, 2009, s. 168. 